\title{
Synthesis review of the Gulf of Gabes (eastern Mediterranean Sea, Tunisia): Morphological, climatic, physical oceanographic, biogeochemical and fisheries features
}

\author{
Béchir Béjaoui $^{\mathrm{a}, *}$, Sana Ben Ismail ${ }^{\mathrm{a}}$, Achref Othmani ${ }^{\mathrm{a}, \mathrm{b}}$, Olfa Ben Abdallah-Ben Hadj Hamida ${ }^{\mathrm{c}}$, \\ Cristèle Chevalier ${ }^{\mathrm{d}}$, Wafa Feki-Sahnoun ${ }^{\mathrm{a}}$, Ali Harzallah ${ }^{\mathrm{a}}$, Nader Ben Hadj Hamida ${ }^{\mathrm{c}}$, \\ Riadh Bouaziz ${ }^{\mathrm{e}}$, Salem Dahech ${ }^{\mathrm{f}}$, Frédéric Diaz ${ }^{\mathrm{d}}$, Khouthir Tounsi ${ }^{\mathrm{g}}$, Cherif Sammari ${ }^{\mathrm{a}}$, \\ Marc Pagano $^{\mathrm{a}, \mathrm{d}}$, Malika Bel Hassen ${ }^{\mathrm{a}}$

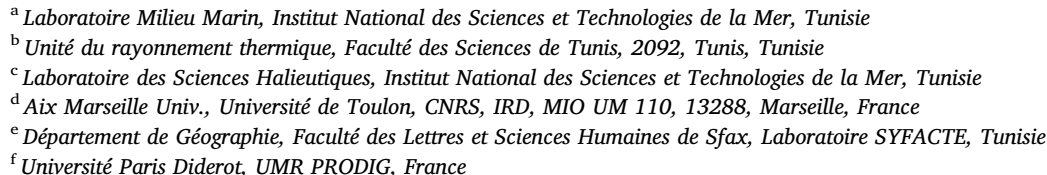

Université Paris Diderot, UMR PRODIG, France \\ ${ }^{\mathrm{g}}$ Institut National de la Météorologie, Subdivision Météorologique de Sousse, Tunisie
}

\section{Introduction}

Several oceanographic surveys have been done in the Gulf of Gabes since the beginning of the twentieth century. The aim of the study by the "Pourquoi Pas"? in 1923 was to investigate sea bottom features (Dangeard, 1924). The benthos research began with Le Danois (1925) and Seurat $(1924,1929,1934)$, who studied the habitats on the intertidal floor. Later, De Gaillande (1970a, b) and Poizat (1970a, b) studied the benthic sands, the hydrodynamics and sediments of the Gulf, while Ktari-Chakroun and Azouz (1971) focused on the bottom typography to identify areas suitable for trawling. During the same period, Ben Othman (1971) published hydrobiological observations on the southeast Tunisian coast. The potential of pelagic fish exploitation was investigated in the frame of the research and development project of fisheries during three combined hydroacoustic and oceanographic cruises (June-July and September-October 1972 and April-May 1973) that enabled a detailed description of oceanographic properties (Brandhorst and Messaoud, 1977). The latter study could be considered the first of its kind, given the investigated geographical space and the subject matter addressed.

Water circulation highly influences the biological, chemical and sedimentological features in the Gulf of Gabes. Previous studies showed that water circulation in the Gulf is closely associated with the Atlantic waters circulating through the Strait of Gibraltar (Béranger et al., 2004; Ben Ismail et al., 2012, 2014) and with tidal effects (Tsimplis et al., 1995; Gasparini et al., 2004). Tides observed in the Gulf of Gabes are among the highest in the Mediterranean Sea (up to $2 \mathrm{~m}$ in height) and are mostly semidiurnal (Gasparini et al., 2004; Sammari et al., 2006). In addition to tides, anticyclonic winds also drive water circulation (Hattour et al., 2010), bed sediment texture and seagrass density (Ben Brahim et al., 2010).

The Gulf of Gabes is considered highly productive (D'Ortenzio and d'Alcalà, 2009; Ben Brahim et al., 2010), contributing approximately $40 \%$ of the national fish production in Tunisia (DGPA, 2015) and thus constituting an anomaly in the eastern Mediterranean Basin, which is known to be oligotrophic, as it is governed by the inflow of usually nutrient-poor Atlantic surface waters coming from Gibraltar (Berman et al., 1984; Krom et al., 2010). The Gulf was recently identified as one of the eleven consensus ecoregions of the Mediterranean and is considered, together with the Venetian shelf region, as a shallow and phytoplankton bloom region (Ayata et al., 2017). Additionally, this area is usually considered an important nursery for several fish species (Hattour et al., 1995; Derbel et al., 2012; Enajjar et al., 2015).

Since the industrialization in 1970, which involves discharge from large-scale phosphate production plants in Sfax and Gabes (Béjaoui et al., 2004; Ghannem et al., 2010), the phosphogypsum discharge ( $\sim 12000$ ton per day) has become the main cause of the disequilibrium of this ecosystem. Recent studies has shown a decrease in fish resources (Zairi and Rouis, 1999; Hamza-Chaffai and Pellerin, 2003); a loss of marine biodiversity (Drira et al., 2008; Barhoumi et al., 2009; Rabaoui et al., 2013) and a degradation of water quality (Bel Hassen et al., 2008; Drira et al., 2014a, b; Ben Salem et al., 2015). The discharges of phosphogypsum led to a drastic decrease in the seagrass areas, as observed for Posidonia oceanica assemblages, which were shown to be 


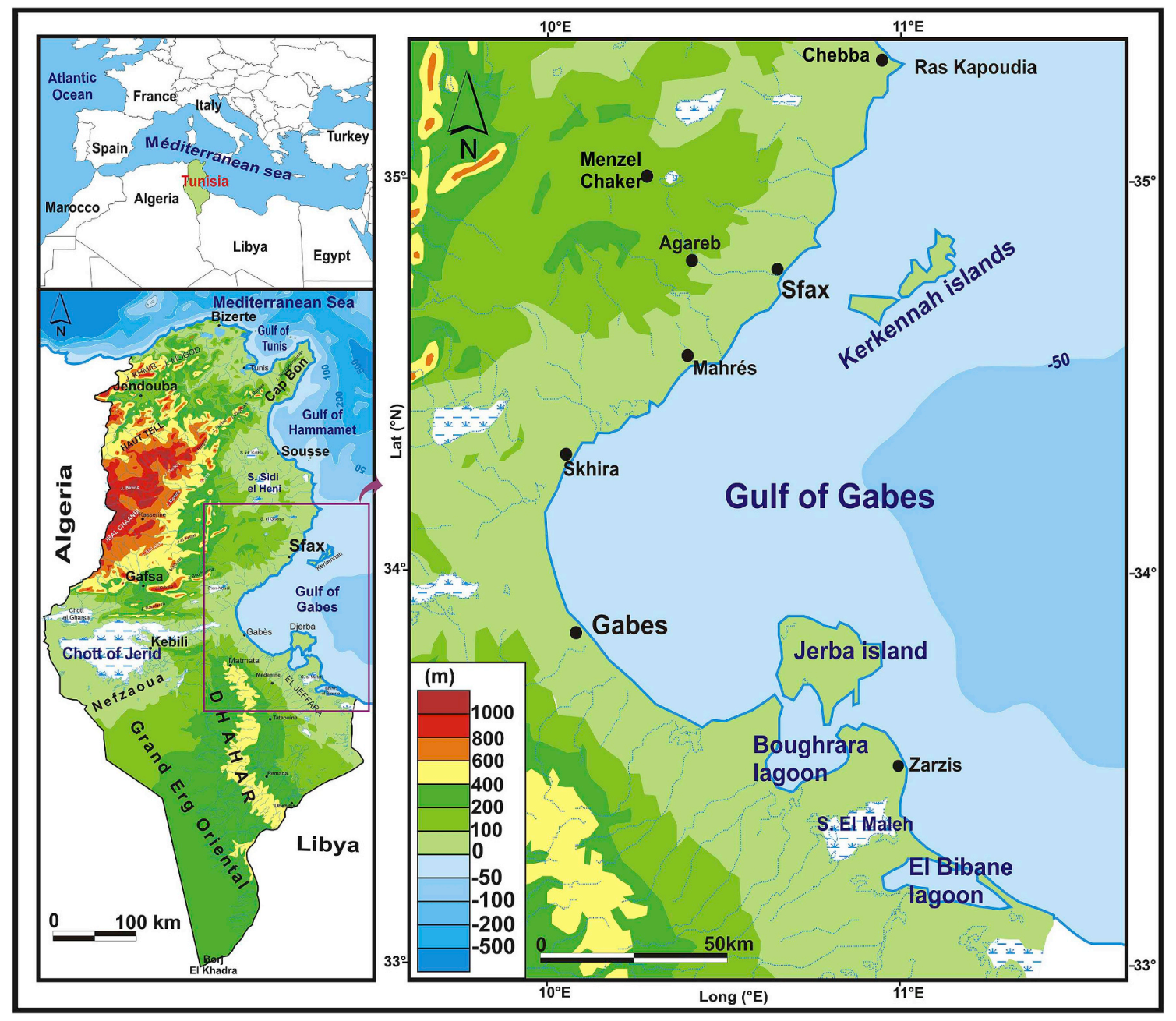

Fig. 1. Localization of the gulf of Gabes.

strongly reduced in the more polluted areas (Béjaoui et al., 2004; Ben Brahim et al., 2010).

Exploitation of marine resources has been a significant component in this historical relationship, and overuse has occurred at different times (Tudela, 2004). Indeed, overfishing caused reductions in fish abundance, biomass and species richness and can disrupt ecosystem functioning, leading to changes in biological assemblages and the degradation of marine ecosystem services (Worm et al., 2006). Mediterranean fisheries are typically multi-species and multi-gear, particularly the demersal fisheries which consist of numerous small to medium-sized boats (Farrugio et al., 1993). This diversity brings additional difficulties to the task of managing fisheries (Papaconstantinou and Farrugio, 2000). Coastal fisheries are particularly important in the southern region of Tunisia, and almost $53 \%$ of the national fishing units (which represents approximately 13000 units, including approximately 400 trawlers) operate in the Gulf of Gabes. Most fishermen along the Gulf coastline are small-scale coastal fishermen (63\%). They compete vigorously with large trawlers and sardine boats based out of the Gulf's main port cities, especially as fish stocks continue to decline from overfishing. In the Gulf stocks are already overfished by more than $30 \%$ (LRMV, 2011) and biodiversity is declining, coinciding with the reduction in submerged aquatic vegetation.

Invasive species represent an added pressure on ecosystem functioning and fisheries. Among the exotic invasive species recorded in the Mediterranean Sea (Galil, 2000; Zenetos et al., 2005), several have been recorded in Tunisian coastal ecosystems and specifically in the Gulf of Gabes; for example, the green algae Caulerpa taxifolia and C. racemosa
(Langar et al., 2002), the pearl oyster Pinctada radiata (Tlig-Zouari et al., 2009), blue portunid crabs Portunus segnis (Rabaoui et al., 2015) and Callinectes sapidus (Mancinelli et al., 2017) and the tropical scyphozoan Rhopilema nomadica (Daly Yahia et al., 2013) (see Fig. 6.)

The purpose of this paper is to provide an in-depth review on the climatic, geomorphologic, physical, biogeochemical, planktonic and fisheries features of the Gulf of Gabes. It is intended to be used as support for stockholders interested in the Gulf ecosystem.

\section{Field location}

The Gulf of Gabes, named "Petite Syrte", is located in the southeastern part of Tunisia with the town of Chebba in the north and the Tunisian-Libyan border in the south (Fig. 1). It occupies a wide continental shelf area (Morzadec-Kerfourn, 2002) and represents approximately $33 \%$ of the Tunisian coastal waters and more than $50 \%$ of the $700 \mathrm{~km}$ long Tunisian coastline (APAL, 2011). It shelters various islands (Kerkennah, Kneiss and Jerba) and lagoons (Boughrara and El Bibane) and several towns, such as Gabes, Sfax, Jerzis and Jerba.

\section{Climate characteristics}

The Gulf of Gabes is characterized by a semi-arid Mediterranean climate influenced by both a wet temperate component coming from the north and east and a dry and hot subtropical Saharan component including sand storms coming from the south (Dahech and Beltrando, 2012a). Two main seasons are observed: the summer (June to 

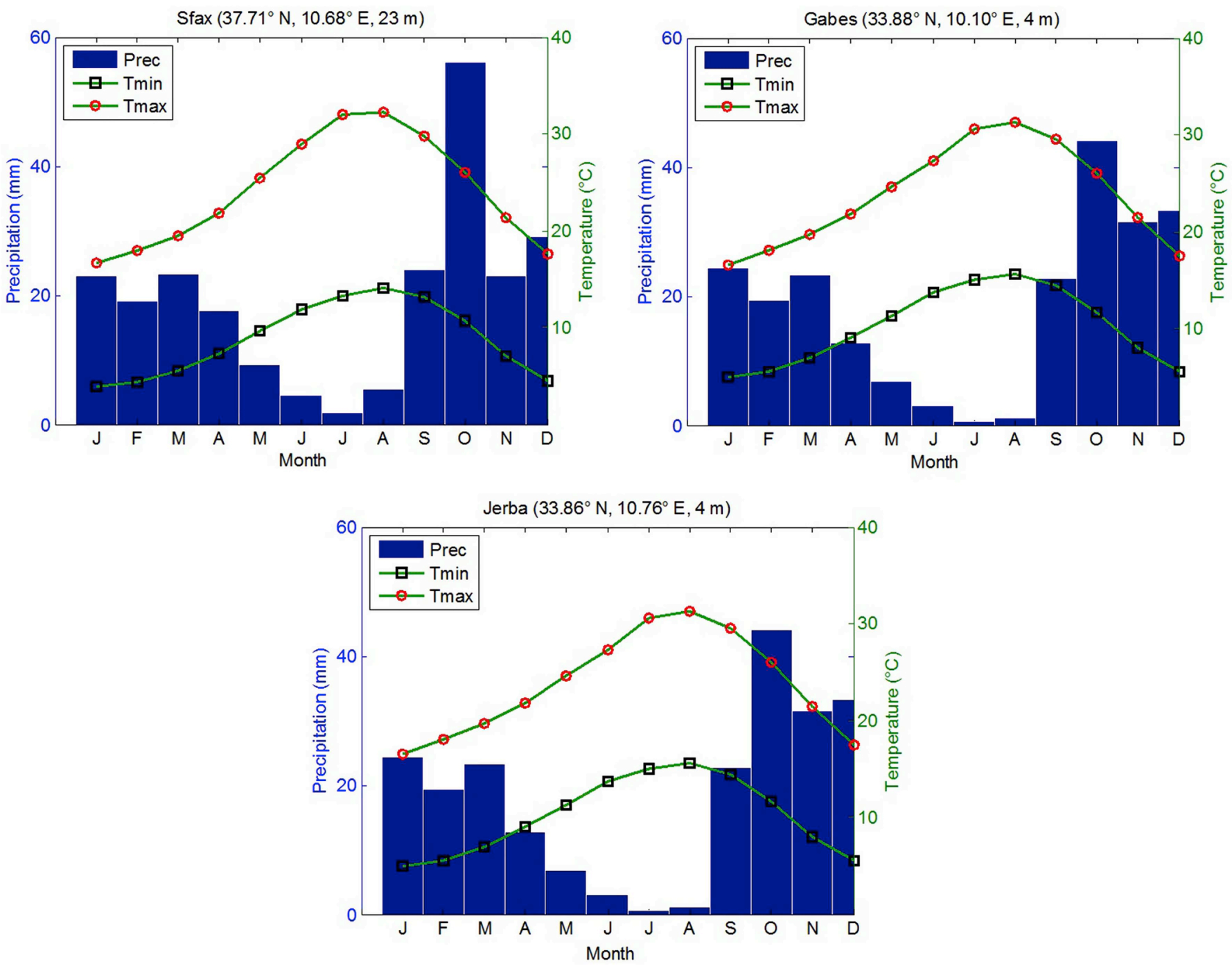

Fig. 2. Mean monthly values of precipitation and temperature for the stations of Sfax (A), Gabes (B) and Jerba (C) (data from National Institute of Meteorology for 1970-2015 period). The total annual precipitations reach $236 \mathrm{~mm}$ in Sfax and 234 in Jerba with $110 \mathrm{~mm}$ in autumn.

September), which is dry and hot, and the winter (January to March), which is wet and cool (Fig. 2). The hot season extends beyond the summer, and the number of sunny days may reach $64.4 \%$ (Amari, 1984). Two intermediate seasons, spring and autumn, may be observed, but the duration depends on the year. The latter is the rainiest season (El Melki, 1996).

The mean temperature is approximately $11^{\circ} \mathrm{C}$ in the winter and approximately $23^{\circ} \mathrm{C}$ during the summer (Atlas Climatique, 1999). Furthermore, the mitigating effect of the sea can be observed on extreme values and their spatial repartition. In fact, the minimum temperature is $+4{ }^{\circ} \mathrm{C}$ at Sfax and $-3{ }^{\circ} \mathrm{C}$ at Gabes, whereas the maximum is $+44{ }^{\circ} \mathrm{C}$ at Sfax and $+50{ }^{\circ} \mathrm{C}$ at Gabes (Bechrawi, 1980). The mean temperature in winter is approximately $12^{\circ} \mathrm{C}$ and $13^{\circ} \mathrm{C}$ in Sfax and Jerba, respectively, whereas during the summer it is $25^{\circ} \mathrm{C}$ in Sfax and $26^{\circ} \mathrm{C}$ in Jerba (Fig. 2).

The precipitation has a strong annual variability from $120 \mathrm{~mm}$ to, exceptionally, $>600 \mathrm{~mm}$ a year (Atlas Climatique, 1999), with up to $650 \mathrm{~mm}$ recorded in Sfax in 1969 (Daoud and Dahech, 2012). The mean annual precipitation for the period 1970-2015 was $236 \mathrm{~mm}$ in Sfax and $234 \mathrm{~mm}$ in Jerba. Forty five percent (45\%) of precipitation occurs in autumn (from 80 to $110 \mathrm{~mm}$ ) and $30 \%$ in winter (from 60 to $80 \mathrm{~mm}$ ), whereas the precipitation is $<5 \mathrm{~mm}$ in summer (Amari, 1984; Atlas Climatique, 1999) (Fig. 2). Rivers in the gulf of Gabes are intermittent with annual flow estimated to 80 million $\mathrm{m}^{3}$ year $^{-1}$ (APAL, 2012). The only continuous inputs in the gulf of Gabes is that of the industrial waste of about 410 million $\mathrm{m}^{3}$ year ${ }^{-1}$ (Béjaoui et al., 2004).

The annual evaporation varies from 1600 to $2000 \mathrm{~mm}$ (Atlas Climatique, 1999) with high temporal and spatial variability; for instance, the monthly evaporation varies from $110 \mathrm{~mm}$ during winter to $210 \mathrm{~mm}$ during summer at Sfax and from 145 to $184 \mathrm{~mm}$ at Gabes. Globally, evaporation (approximately $1790 \mathrm{~mm}$ a year) is not balanced by precipitation (approximately $230 \mathrm{~mm}$ a year) and river inputs ( 80 million $\mathrm{m}^{3}$ a year). Consequently, the freshwater budget is estimated to be approximately $-1400 \mathrm{~mm}$ a year (Bethoux, 1977).

The average annual wind intensity is approximately $3.5 \mathrm{~m} \mathrm{~s}^{-1}$ (Dahech, 2007) and rarely exceeds $8 \mathrm{~m} \mathrm{~s}^{-1}$. The dominant wind originates from the eastern sector, corresponding usually to sea breeze (Dahech, 2007). Dust wind, which may cause some damage, comes mainly from the southwest. Its frequency ranges from 12 days year ${ }^{-1}$ in Sfax to 20 days year ${ }^{-1}$ in Gabes and 18 days year ${ }^{-1}$ on Jerba Island (Dahech and Beltrando, 2012b). During the winter, the prevailing wind is from the western sector. Coming from the continent, this wind is often cold and dry. During summer, the prevailing wind is mainly from the eastern sector (Dahech and Beltrando, 2006). Sea breeze circulation is the most frequent (Dexter, 1958; Dahech et al., 2006), and since it comes from the sea, it is humid. This local wind improves the thermal 
comfort near the coasts (Dahech, 2015). During autumn and spring, the alternation of unsteady eastern, northern and western winds occur (Dahech, 2007).

The mean annual solar radiation is approximately $208 \mathrm{Wm}^{-2}$, ranging from $292 \mathrm{~W} \mathrm{~m}^{-2}$ during August to $104 \mathrm{~W} \mathrm{~m}^{-2}$ during January (Beltrando, 2004). During the summer, when the day-length is approximately $16 \mathrm{~h}$, the insolation duration reaches $350 \mathrm{~h}$ per month in Sfax and Jerba. The duration of insolation decreases in winter to $200 \mathrm{~h}$ per month (Atlas Climatique, 1999).

\section{Coastal morphology}

The coastal morphology of the Gulf shows varied forms (Brahim, 2001; Oueslati, 2004; Kouka, 2015).

Beaches (Fig. 3) are mostly located at the mouth of wadis (e.g., Chaffar beach formed by two spits approximately $8 \mathrm{~km}$ long and 40-150 m wide), on the southern coast of Gabes (Miossec and Paskoff, 1979) and at the eastern facades of Jerba Island (from the spit of R'mel to Aghir) and the Zarzis peninsula (Oueslati, 2004; Bourgou and Kassah, 2008). Elsewhere, they are very discontinuous and often take the form of narrow sandy beaches a few meters wide without shorefront dunes (Oueslati, 2004; Bouaziz, 2011), as observed in bays and the downslope of cliffs. Locally, they correspond to undeveloped spits, e.g., Botria spit and Sebkhet Driaa in the south of Skhira. The large beaches located in tourist areas have suffered irreversible degradation for several decades (Paskoff, 1985; Bourgou and Kassah, 2008). The most significant examples are Chaffar and Teboulbou, characterized by a relatively high erosion rate between 1.5 and $2 \mathrm{~m}$ a year (Oueslati, 2004). In addition to sea level rise and land subsidence, this erosion is mainly linked to 1) urban developments, 2) the construction of dams in the catchment areas shortening the sediment supply, and 3) the absence of wadis supplying sediment to intertidal zones, as on the Kerkennah Islands, Jerba and the coast located between Ras Kaboudia (Chebba) and El Awabed north of Sfax (Paskoff, 1985; Bouaziz et al., 2005; Bouaziz, 2011).

Cliffs can exceed $8 \mathrm{~m}$ (Oueslati, 2004; Kouka, 2015), as in Jorf and Borj El H'ssar (west coast of Kerkennah), Ouled Gacem (east coast of Kerkennah), Skhira-Nadhour, Ras El Jorf (in front of Jerba) and Karboub in the east of the Gulf of Boughrara (Kouka, 2015) (Fig. 3). They often consist of fragile formations (e.g., sandy clays rich in gypsum and silty sands) (Oueslati, 2004; Kouka, 2015) crossed by numerous ravines. Deep notches are often observed in their bases, evidencing severe and rapid degradation of the coasts, and therefore, large blocks are found at the base of these cliffs. This phenomenon is remarkable, especially at Skhira, Ras El Jorf (facing Jerba Island) and Karboub (eastern sector of Boughrara) (Oueslati, 2004). Elsewhere, the cliffs are between 1 and $5 \mathrm{~m}$ high. They are carved in relatively resistant (in particular, marine or wind sandstone of upper Quaternary) or heterogeneous (alternation of Quaternary sandstone, colluvium and alluvium) rocks (Bourgou and Kassah, 2008; Bouaziz, 2011). They are observed along the coast from Ras Kaboudia in Sfax (Melloulèche, Louza, Awabed ...), on the Kerkennah Islands and Jerba (Aghir, Sidi Yati, Guellala ...), on the northern coast of Gourine, on the Zarzis peninsula and in the "slobs" that isolate Bhiret El Bibane Sea (Oueslati, 2004).

Wetlands cover a large area (Fig. 3), consisting of sebkhas (salted land without vegetation), chotts (salted land with salt-tolerant vegetation), tidal marshes, and lagoons (Morzadec-Kerfourn, 2002; Bouaziz, 2011). The sebkhas and chotts cover a large part of the Gulf coast and almost $2 / 3$ of the Kerkennah Islands. They are in direct contact with the sea behind the sandy beaches, and they often border the tidal marshes. These dominant landscapes are observed on the coast of Melloulech, Mahres and Ouadrane and particularly around the Zarzis peninsula and the El Bibane Lagoon (Oueslati, 1992; Kouka, 2015). The salt marshes are composed of two separated parts: "the slikke" (regularly emerged and submerged part depending on the tide) and "the schorre" (visible part with a halophyte vegetation sometimes crossed by a dense tidal channel network) (Oueslati, 1992). Their evolution and extension are strengthened by the tide importance as well as by some sheltered coastal areas; thus, they mainly extend in bay beds and estuaries (Oueds Ouadrane, El Maleh and Kerkennah) or behind shelter spits (spits of Chaffar, Skhira, Botria and Ras R'mel and the two peninsulas of Lella El Hadhria and El Gastil) (Oueslati, 2004). Lagoons are only found in the southern part of the Gulf, such as the Boughrara and El Bibane Lagoons. Their development is related to morphological evolution since the Versilian transgression (Bouaziz et al., 2003).

Generally, coastal areas have been experiencing significant changes over time, enhanced by climate change and related sea level elevation (Bouaziz, 2011). This phenomenon was revealed by several observations, such as high rates of land salinization and coastal erosion (Oueslati, 1992; Bouaziz, 2011).

\section{Physical oceanography}

The circulation in the Gulf is mainly influenced by the effects of the tides and anticyclonic winds (Abdennadher et al. 2006; Sammari et al., 2006; Poulain and Zambianchi, 2007). The bottom topography, sediment texture, and relatively high density of seagrass beds (Zostera, Cymodocea and Posidonia) and algae (Caulerpa) contribute to the complexity of the hydrodynamic nature of the area.

\subsection{Permanent currents}

The Atlantic Tunisian Current (ATC) (Sammari et al., 1999), a permanent surface current with an Atlantic origin, is characterized by its minimal salinity as it travels through the Tunisia-Sicily Channel and flows along the Tunisian coast between 0 and $200 \mathrm{~m}$ (Sorgente et al., 2011; Ben Ismail et al., 2012). This current is primarily oriented towards the south and is then divided into two branches in front of the Gulf of Gabes: a coastal branch (between the coast and $80 \mathrm{~km}$ ) facing south, where the Atlantic Water (AW) becomes saltier $(\mathrm{S}>38$ ) (Ben Ismail et al., 2010), and a less salty branch (S of approximately 37.4-37.7) flowing over $180 \mathrm{~km}$ off the coast with a southeast direction along the Libyan shelf (Millot et al., 2006; Ben Ismail et al., 2010). This current was recently identified as the Atlantic Libyan Current (ALC) (Sorgente et al., 2011; Ben Ismail et al., 2015).

The Gulf of Gabes occupies a vast shallow area, making it more sensitive to atmospheric effects (e.g., wind). Its particular the bathymetry (less than $50 \mathrm{~m}$ to $110 \mathrm{~km}$ from the coast and up to $200 \mathrm{~m}$ to $400 \mathrm{~km}$ from the coast) strongly influences its hydrodynamics, with a general circulation characterized by high mesoscale variability. Several studies have demonstrated the almost permanent presence of an anticyclonic vortex south to $34^{\circ} \mathrm{N}$, named "Sydra Gyre" (SG) (Ciappa, 2009; Sorgente et al., 2011). A mainstream of the north-south current accompanies a reverse south-north current (Hattour et al., 2010). These currents are involved in the renewal of the Gulf waters and fuel an anticyclonic circulation (more or less intense according to the season), causing an average elevation of approximately $20 \mathrm{~cm}$ in the shallow regions. However, these currents remain low compared to those induced by tides (Fig. 4).

\subsection{Tides and tidal currents}

In the Gulf of Gabes, the tide is predominantly semi-diurnal with diurnal inequality $(\mathrm{O} 1+\mathrm{K} 1) /(\mathrm{M} 2+\mathrm{S} 2)<0.1$ (Abdennadher et al. 2006; Othmani et al., 2017). The M2 and S2 semidiurnal components are well developed in the Gulf (coastal areas and central part) but are reduced in the offshore regions. The other semidiurnal components, N2 and $\mathrm{K} 2$, are of reduced amplitude, $<3 \mathrm{~cm}$ (Tsimplis et al., 1995; Gasparini et al., 2004; Othmani et al., 2017). The Gulf has the highest tidal range in the Mediterranean Sea (maximum $>2 \mathrm{~m}$ ) essentially due to the low slope of the continental shelf and the shallow depth, which maintains its horizontal dimensions close to the resonance condition 


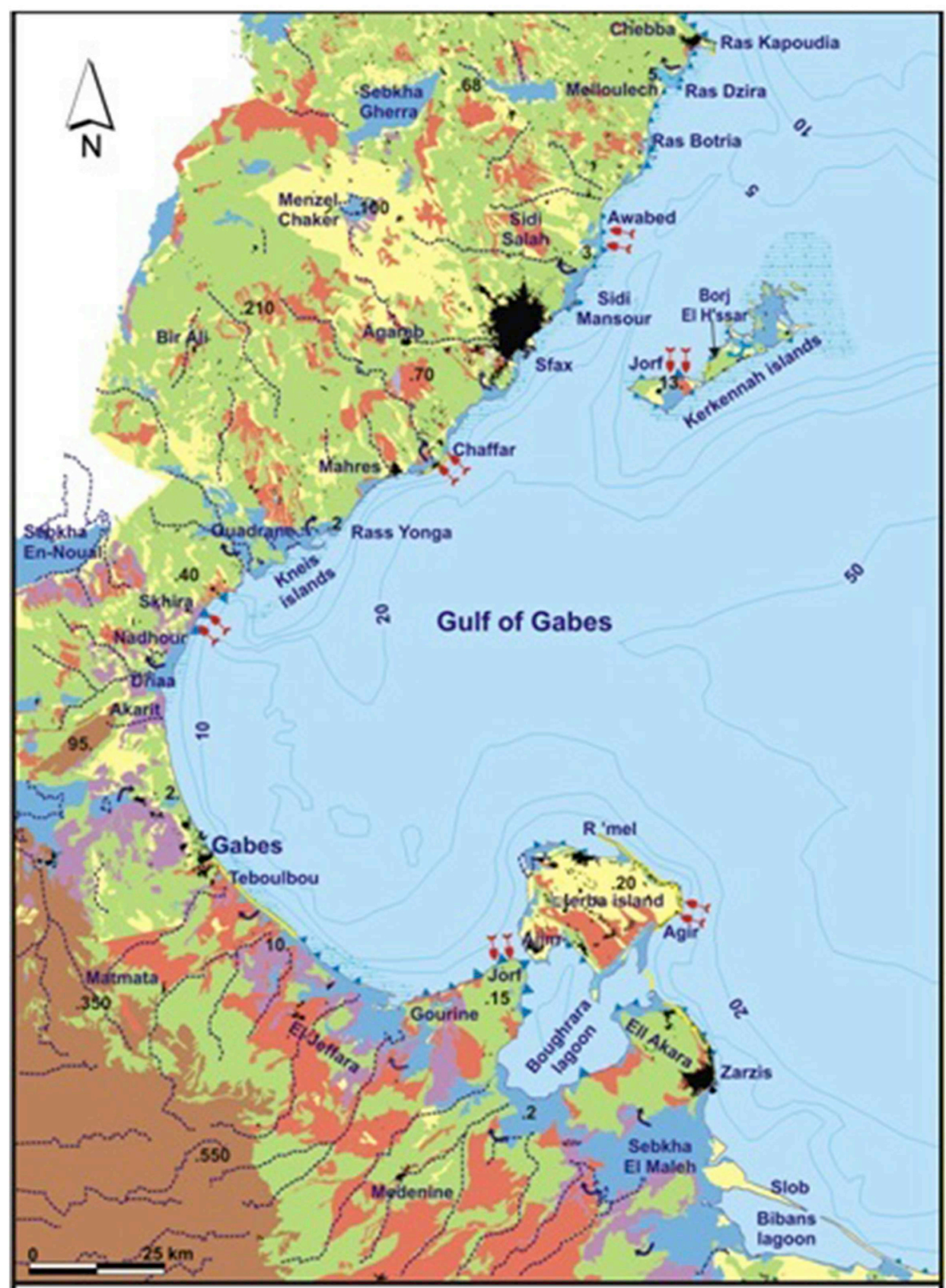

\begin{tabular}{|c|c|c|c|}
\hline \multicolumn{2}{|c|}{ Topography and Hydrology } & \multicolumn{2}{|c|}{ Coastal and submarine landforms } \\
\hline .10 & Kote & $\because 3$ & Tyrrhenian sandstone \\
\hline-5 & Isobath & & Wetlands (Sebkhas, Strotts and Salt Marshes) \\
\hline- & Wadi & $\ldots$ & Shalloness \\
\hline \multirow{2}{*}{\multicolumn{2}{|c|}{$\begin{array}{l}\text { Geological structure and Quaternary } \\
\text { continental landformes and deposits }\end{array}$}} & $\square$ & Sandy beach \\
\hline & & $A N$ & Cliff between $10-20 \mathrm{~m}$ \\
\hline & Strousturalourface & $\ldots$ & Cliff between $1-10 \mathrm{~m}$ \\
\hline & Btructurai surtace & $\ldots$ & Cliff less than $1 \mathrm{~m}$ \\
\hline & Limstone crust (Middel and lower Pleistocene) & \multicolumn{2}{|c|}{ Costal dynamics } \\
\hline & \multirow{4}{*}{$\begin{array}{l}\text { Alluvium and colluvium (upper Pleistocene and } \\
\text { bolocene) } \\
\text { Gypssum crusts (Holocene) } \\
\text { Historic and present-day deposits }\end{array}$} & 20 & \multirow{3}{*}{$\begin{array}{l}\text { Area submitted to severe coastal erosion } \\
\text { Coastal Sebkha and Shott extension }\end{array}$} \\
\hline & & L & \\
\hline & & Anth & \\
\hline & & & Buildings \\
\hline
\end{tabular}

Fig. 3. Geomorphology of the gulf of Gabes. 


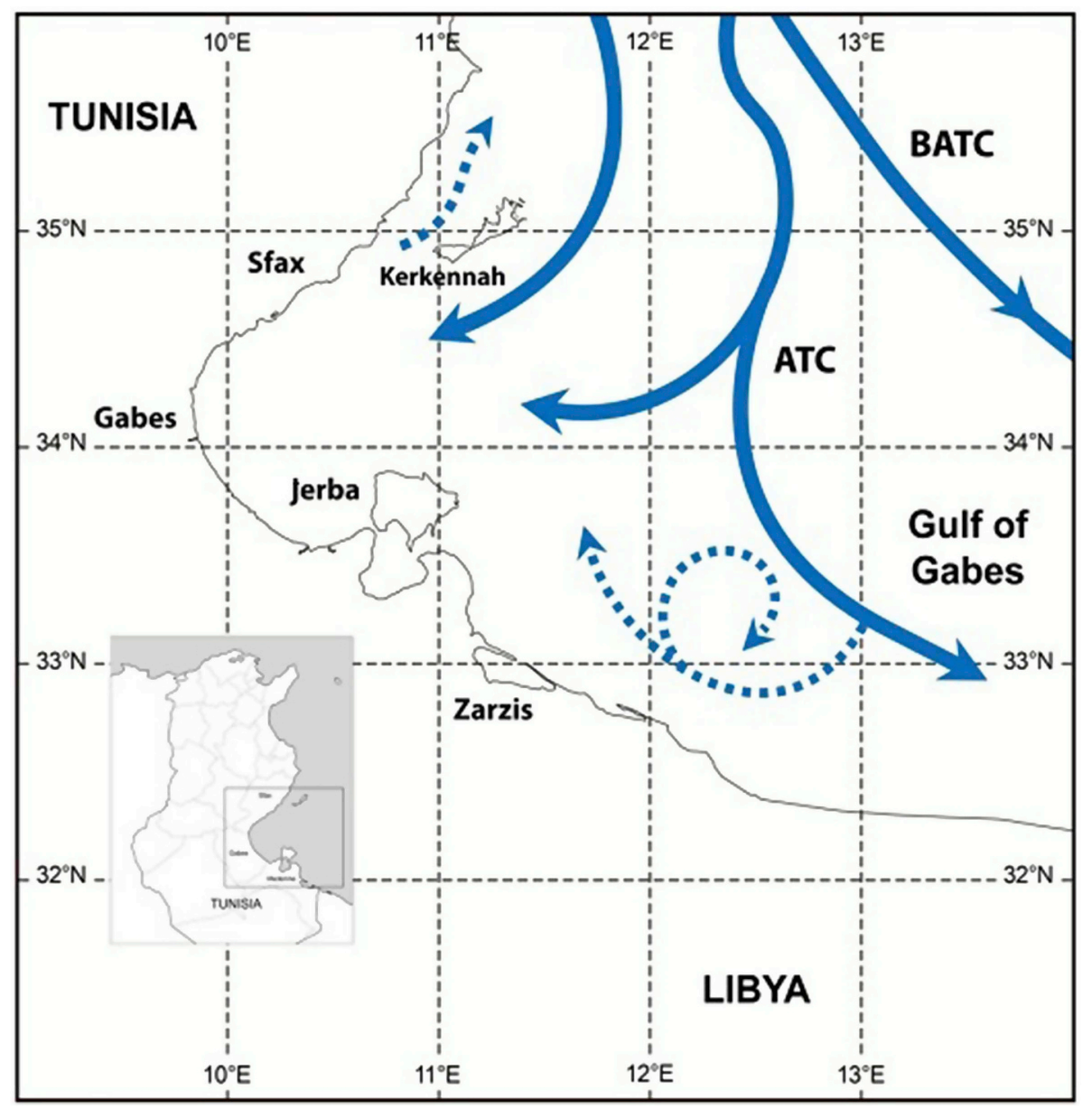

Fig. 4. Schematic illustration of the main pathways of the principal water masses flowing through the Gulf of Gabes: BATC (Bifurcation Atlantic Tunisian Current) and ATC (Atlantic Tunisian Current) (Ben Ismail et al., 2015).

(1/4 of the wavelength of the semi-diurnal tidal wave incidence) (Othmani et al., 2017). The tide produces a stationary wave whose amphidromic points are distributed around the island of Pantelleria and that resonates in the Gulf of Gabes (Sammari et al., 2006). The Gulf is thus a tide amplifier with a greater tidal range in the central part than on the coast. The tidal amplitude reaches $2.3 \mathrm{~m}$ in the central part of the Gulf during the spring tide (Sammari et al., 2006) and $0.2 \mathrm{~m}$ during the neap tide (Ayari et al., 2008). However, along the coast, the high bottom friction (dissipating $61 \%$ of the energy) decreases the tidal amplitude (e.g., $0.8 \mathrm{~m}$ in Ras Kaboudia and $1.6 \mathrm{~m}$ in Ras Jdir during spring tide) (Sammari et al., 2006) and causes a phase lag exceeding $3 \mathrm{~h}$ at the lagoon of Boughrara and $4 \mathrm{~h}$ at El Kantara.

Parallel to the coast, tides induce periodic currents whose intensity can be high in some places, as shown in Fig. 5 (Othmani et al., 2017). Based on the geographic distribution of the maximum amplitude and the phase of the M2 wave (Molines, 1991), Tounsi (1998), the surface current is approximately $10-30 \mathrm{~cm} \mathrm{~s}^{-1}$ in shallow areas and can reach $50 \mathrm{~cm} \mathrm{~s}^{-1}$ in topographic shallow corridors during spring tides, as confirmed by in situ measurements (Sammari et al., 2006; Hattour et al., 2010). Currents are as periodic as tides; during the flood, they flow coastward and fill the Gulf, whereas during the ebb, they flow eastward and empty the Gulf (Othmani et al., 2017). The water masses coming from the Gulf's eastern sector bifurcate into two branches. One is directed to the northern sector, towards the Kerkennah Islands, and the other to the southern sector, towards Jerba Island. In the north, the currents surround the Kerkennah Islands on both the northern and southern sides, meeting in the channels. At the level of Ras Kaboudia, the current bifurcates into two branches, the first moving northward and the second going towards Sfax Harbor. In the south, the current moves toward the western inlet of the Boughrara Lagoon, where the tidal currents feed the lagoon from both the east and the west (Othmani et al., 2017). The currents follow approximately the same path during flood and ebb tides, but they move in substantially opposite directions and at slightly different intensities.

\subsection{Wind currents}

The currents induced by winds are often parallel to the coast and may be hampered by the low water level. The currents due to storms can be superimposed onto tidal movements, provoking significant elevations of the sea level (LCHF, 1979). Amari (1984) showed that under the action of local or broader winds, the currents can be 2 to 5 times stronger than the tidal currents, especially in the presence of "marine" winds, whose influence is clearly higher than that of the "earthly" winds (Morellato, 2008).

\subsection{Wave currents}

The dominant waves in the Gulf of Gabes are NNW and ESE (WAMDI Group, 1988), with a height varying between 2 and $4.8 \mathrm{~m}$ and a period of $10 \mathrm{~s}$ (measurements beyond a $20 \mathrm{~m}$ depth over a 20-year period; 1974-1994) (Hydrotécnica Portuguesa, 1995). However, the significant height of these waves experienced a slight increase over 50 years. During storms, waves generated offshore are quite unstable and 

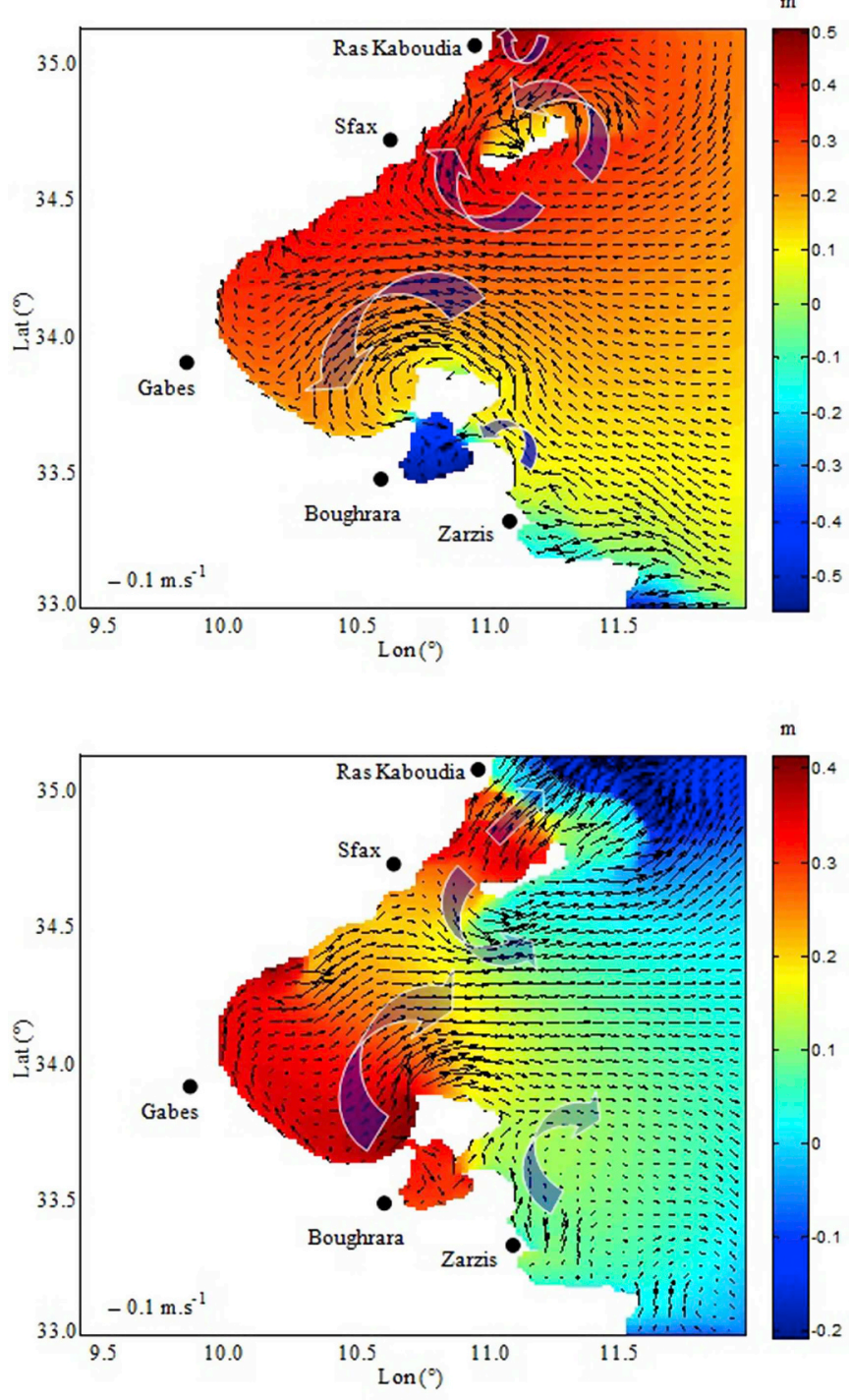

Fig. 5. Simulated surface tidal currents and water level spatial distribution during flood tide (A) and ebb tide (B). Arrows indicate the current directions and colours designate the water level above the mean depth (Othmani et al., 2017). (For interpretation of the references to colour in this figure legend, the reader is referred to the Web version of this article.)

spread mainly in the NE, ENE and SE sectors, with significant heights estimated at $5.4 \mathrm{~m}, 6.3 \mathrm{~m}$ and $7.7 \mathrm{~m}$, respectively. They dampen near the coast because of the gradual slope of the ground, shallow depth, and seagrass beds present on the coast. The most significant action of the waves is particularly evident along the Bin El Ouediane coastline by sand spit edification (Ayari et al., 2008).

\subsection{Hydrology}

The warm climate of Tunisia promotes evaporation and increases the salinity and temperature of water masses. The mean annual salinity and temperature are relatively high, approximately 38.00 and $19.4^{\circ} \mathrm{C}$, respectively (Ben Ismail et al., 2010; Ben Brahim et al., 2013). The seasonal variation of temperature is particularly important in the Gulf of Gabes, varying from $13{ }^{\circ} \mathrm{C}$ in the winter to $26^{\circ} \mathrm{C}$ in the summer. Seasonal variations of salinity are also observed, particularly in the coastal area of the Gulf, where the salinity may exceed 39.00 in summer (Ben Brahim et al., 2013). The water column is well mixed during the winter, whereas vertical stratification is observed from May to October.
Recent studies show that the stratification varies with depth (Bel Hassen et al., 2008, 2009a, b; Ben Ismail et al., 2010). In deep areas ( $>70 \mathrm{~m}$ ), vertical stratification is more pronounced due to the presence of cold and less salty Atlantic water. In more shallow areas $(<60 \mathrm{~m})$, the water column is well mixed with an average salinity of 37.90 and an average temperature varying between $21.6^{\circ} \mathrm{C}$ at the surface and $20.6^{\circ} \mathrm{C}$ at the bottom in summer conditions (Ben Othman, 1973; Bel Hassen et al., 2009a, b), when the water mass with an Atlantic origin is more difficult to characterize.

\subsection{Present-day and future climate}

The Gulf of Gabes is particularly interesting for the study of the impacts of climate change on coastal ecosystems (Rizzi et al., 2016). Indeed, its shallowness and large continental shelf make it specific for the Mediterranean Sea (Morzadec-Kerfourn, 2002). Strong air-sea interactions in such shallow water lead to strong seasonal variations of the water temperature and to very high sensitivity to any change in the weather conditions (Sorgente et al., 2002). The air temperature, a key indicator of climate evolution (Sanchez-Arcilla et al., 2011), strongly increased in the region during the last decades, as illustrated by the high increasing rates of summer maximum daily temperature for the period of $1974-2007$ : approximately $0.6^{\circ} \mathrm{C}, 0.7^{\circ} \mathrm{C}$ and $0.67^{\circ} \mathrm{C}$ per decade in Sfax, Jerba and Gabes, respectively (Hemming et al., 2013). This air warming led to a lengthening of the summer season at a rate of 8 days per decade and stagnation or even a slight decrease in the rainfall amount (Harzallah et al., 2010). Simultaneously with this atmospheric warming, a warming trend of water temperature at a rate of $+0.12{ }^{\circ} \mathrm{C}$ per decade was observed between 1920 and 2007, although the data set is sparse and limited in amount (Harzallah et al., 2010).

Recently developed coupled atmosphere-ocean regional climate models (RCMs) for the Mediterranean Sea predict an accelerating increase in air and water temperatures during the next decades (Taylor et al., 2012; Goodess, 2013; Gualdi et al., 2013; Jacob et al., 2014). According to these scenarios, the air temperature will increase approximately $1.5^{\circ} \mathrm{C}$ in the $2021-2050$ period relative to the $1961-1990$ one. On the other hand, a marked decrease in rainfall may occur after 2020 ( $-20 \mathrm{~mm}$ between the 2021-2050 and 1961-1990 periods). These changes will likely impact the water properties of the Gulf (Harzallah et al., 2010; Goodess, 2013; Gualdi et al., 2013). A tentative study of the potential impacts of these changes (Sanchez-Arcilla et al., 2011) considered that the water quality of the Gulf may decrease by $20 \%$ due to decreased precipitation (through reduced dilution) and by $10-50 \%$ due to an increase in the water temperature (through reduced dissolved oxygen content). The warming of the waters would also lead to the appearance of marine alien species. Nearly 40 species have been observed in the Gulf of Gabes between 1966 and 2006 (Agnew et al., 2013). The number of alien species is projected to be approximately 80-100 by 2050 (Goodess, 2013).

The coasts of the Gulf of Gabes, mainly formed by lowlands, are highly vulnerable to sea level rise (Morzadec-Kerfourn, 2002). At the scale of the Mediterranean Sea, level reconstructions show trends between $+0.88 \mathrm{~cm}$ and $+1 \mathrm{~cm}$ per decade for 1960-2000 and between +1.1 and $+1.3 \mathrm{~cm}$ per decade for the more recent period of 1993-2000 (Calafat et al., 2012; Jordà and Gomis, 2013). These rates are slightly lower than the rate reported at the global scale $(+1.8 \mathrm{~cm}$ per decade; Ulbrich et al., 2013; Bonaduce et al., 2016) or for the Mediterranean Basin based on altimetry $(+2.1 \mathrm{~cm}$ per decade for 1992-2005; Criado-Aldeanueva et al., 2008). At the scale of the Gulf of Gabes, the sea level increase is much higher: $+2.6 \mathrm{~cm}$ per decade for 1998-2009 in Sfax's harbor (Harzallah et al., 2010) based on the Tunisia National Marine data. The scenarios recently provided by the RCMs (e.g., Gualdi et al., 2013) show a rate of $+3.1 \mathrm{~cm}$ per decade between 2021 and 2050, but this corresponds to the increase due to the steric effects. 


\section{Biogeochemical and planktonic features}

\subsection{Nutrients}

Contrary to most parts of the eastern Mediterranean Sea (Thingstad et al., 2005; Krom et al., 2010), the Gulf of Gabes does not show a summer nutrient exhaustion, and some seasonal and coastal-to-offshore variations have been already observed (Drira et al., 2010). In coastal areas, the vertical distribution is almost homogeneous throughout the water column and shows a decreasing trend with depth (Drira et al., 2010; Hannachi et al., 2009; Ben Ltaief et al., 2015). The sources of nutrients have not yet been clearly identified since (i) the watershed inputs remain low, (ii) the large continental shelf prevents local nutrient accumulation in deep waters (Bel Hassen et al., 2008) and (iii) the AW flow does not bring significant amounts of nutrients (Bel Hassen et al., 2009a). The observed year-round availability of nutrients may be due to several other factors, such as efficient remineralization and/or nitrogen fixation due to the abundance of diazotrophs (Drira et al., 2016a; Hamza et al., 2016) or high depositions of phosphorus-enriched Saharan dusts (Taieb and Ben Brahim, 2014; Hamza et al., 2016). A recent study revealed that most atmospheric deposition occurred during the wet season, confirming that wet deposition is the main pathway of nutrient deposition in the Gulf (Khammeri et al., 2018). The inorganic nitrogen deposition is low compared to other Mediterranean regions, whereas phosphorus deposition is within the range of observations made in the eastern Mediterranean Basin. High organic nitrogen and phosphorus atmospheric deposition is also observed (Khammeri et al., 2018), corresponding to increases of heterotrophic prokaryote abundances and carbon biomass, suggesting a possible contribution of bacteria to the organic nutrient pool driven by atmospheric deposition (Khammeri et al., 2018).

Nitrate is the major form of dissolved inorganic nitrogen in winter mixing conditions, while the ammonium concentration strongly increases during the summer stratification period (Drira et al., 2008; Bel Hassen et al., 2009b). A putative nitrogen limitation has already been reported during the late-winter and late-spring (Geurmazi et al., 2010; Ben Ltaief et al., 2017). The silica limitation has been associated with the summer oligotrophic conditions highlighted by both low chlorophyll biomasses and high concentrations of particulate organic matter (Bel Hassen et al., 2010). Phosphorous concentrations are low in the open sea compared to the very high concentrations recorded in coastal areas (Drira et al., 2014a, b; Ben Salem et al., 2015). The lowest concentrations are recorded during stratified conditions corresponding to the summer season (July and September), while the maximum concentrations are recorded during the spring season (Bel Hassen et al., 2009b; Drira et al., 2016b).

\subsection{Chlorophyll pigments}

Along the coast of the Gulf, a high annual variability of chlorophyll is observed (Bel Hassen et al., 2009a). The highest concentrations are recorded close to the coast of Jerba and Kerkennah Islands with concentrations generally below $0.5 \mu \mathrm{g}^{-1}$, whereas the lowest concentrations about $0.03 \mu \mathrm{g}^{-1}$ in average are observed in the open sea (Drira et al., 2010). Concerning the vertical distribution of chlorophyll $a$, recent studies confirmed a weak gradient in well mixed coastal areas and in offshore thermally stratified waters (Bel Hassen et al., 2008; Drira et al., 2010).

The variation in phytoplankton pigments and associated community composition were also examined in relation to the water mass properties (Bel Hassen et al., 2008, 2009a; Drira et al. 2009, 2014b; Hannachi et al., 2009). The phytoplankton pigments are generally low year-round with spatial and temporal variations depending on water mass origins and mixing conditions (Bel Hassen et al., 2008, 2009a; Drira et al., 2009, 2014b; Hannachi et al., 2009). Chlorophytes contribute up to $40 \%$ of chlorophyll $a$ during winter mixing (Bel Hassen et al., 2008,

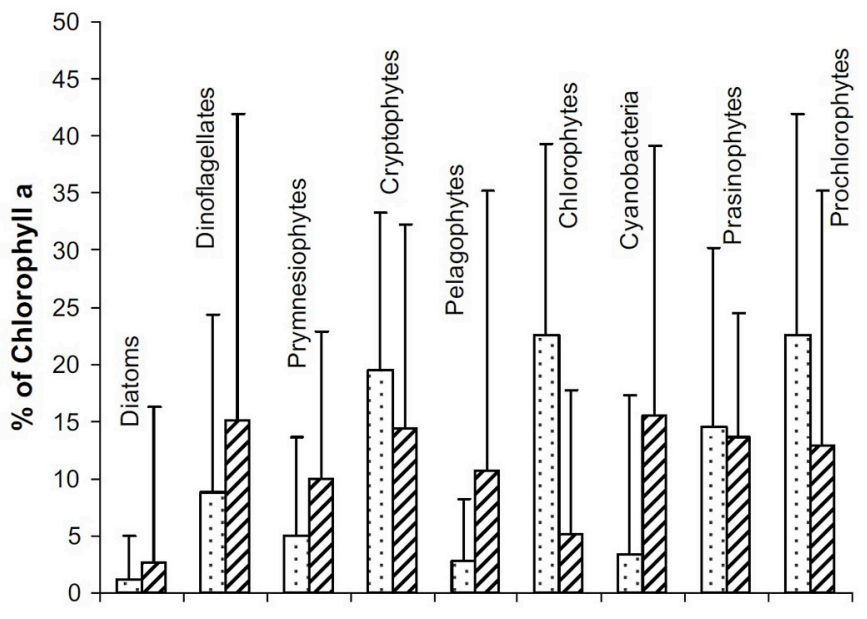

May-June September

Fig. 6. Mean (plus the standard deviations) relative contributions (\%) of phytoplankton classes to chlorophyll a biomass (expressed in percentage) calculated by CHEMTAX for May-June and September cruises (Bel Hassen et al., 2009b).

2009a), whereas Bacillariophytes (mainly diatoms) do not exceed $17 \%$ (Fig. 6). During the early stratification period, chlorophytes, cryptophytes and prochlorophytes contribute to $65 \%$ of total chlorophyll $a$. A significant change occurs during strong stratification, with a decrease in chlorophytes followed by prochlorophytes, while cyanobacteria increase their contribution to the autotrophic biomass (Bel Hassen et al., 2009b; Drira et al., 2016a). The contributions of the autotrophic prokaryotes (cyanobacteria and prochlorophytes) to total chlorophyll $a$ are $26 \%$ and $28 \%$ on average (Bel Hassen et al., 2009b; Drira et al., 2016a), which is in the range of ratios reported for areas of the southern Mediterranean Sea (Barlow et al., 1997). The chlorophyll $a$ biomass is dominated by picoplankton and nanoplankton that contribute up to $80 \%$ of total chlorophyll $a$. This situation is similar to that reported in the eastern Mediterranean Basin (Vidussi et al., 2001) and in the northwestern Basin (Marty et al., 2008): approximately $87 \%$ for these size groups.

The chlorophyll $a$ concentrations observed in the Gulf of Gabes $\left(<0.5 \mu \mathrm{g}^{-1}\right)$ are in the lower range of values currently reported for the Mediterranean Sea, e.g., on the eastern Mediterranean Sea costs $\left(0.40 \mu \mathrm{g}^{-1}\right)$ (Berman et al., 1986; Gitelson et al., 1996; Yacobi et al., 1995), in the Alboran Sea (Corsini et al., 2002; D'Ortenzio et al. 2002) and the Gulf of Lions (0.06-1.7 $\mu \mathrm{g}^{-1}$ ) (Bosc et al., 2004; HarmelinVivien et al., 2008), in the Levantine Basin of the eastern Mediterranean Sea $\left(<0.2 \mu \mathrm{g}^{-1}\right.$ ) (Bosc et al., 2004; Ignatiades et al., 2009; BermanFrank and Rahav, 2012), and in the northwestern coastal zone $\left(0.50 \mu \mathrm{g}^{-1}\right)$ (Thingstad et al., 1998; D'Ortenzio et al 2002). These rather low concentrations highlight the oligotrophic character of the Gulf of Gabes (Bel Hassen et al., 2009a, b; Drira et al., 2010; Ben Ltaief et al., 2015). The maximum concentrations are measured during the late spring at the beginning of the stratification period, while the lowest concentrations are found during the summer when the stratification is the strongest (Bel Hassen et al., 2008, 2009b; Drira et al., 2009; Ben Ltaief et al., 2017).

\subsection{Phytoplankton}

In the Gulf of Gabes, the coastal area shows signs of eutrophication (Ayari et al., 2008; Katlane et al., 2013). Five main classes of phytoplankton are reported in the open sea area, including dinoflagellates (25\%), diatoms (16\%), cyanobacteria (17\%), dictyochophytes $(41 \%)$, and euglenophytes (1\%) (Drira et al., 2009, 2010; Hannachi et al., 
2011). In the coastal area, the phytoplankton community includes Dinophyceae (108 taxa), Bacillariophyceae (58 taxa), Cyanobacteria (5 taxa), and other groups, such as Dictyochophyceae, Euglenophyceae, Coccolithophorideae, and Chlorophyceae represented by only one species (Feki-Sahnoun et al. 2014, 2018a). Among the recorded species, five were declared as toxic: Alexandrium minutum, Coolia monotis, Karenia selliformis Protoceratium reticulatum (Feki-Sahnoun et al. 2017, 2018b) and Ostreopsis cf. ovata (Abdennadher et al., 2016). The cyanobacteria grow throughout the water column with a high density recorded at the thermocline and are associated with the presence of Trichodesmium erythraeum and Pseudanabaena galeata, which contribute to 41 and $50 \%$, respectively, of the total cyanobacteria abundance (Drira et al., 2009, 2010; 2016a). The abundance of cyanobacteria was found to be positively correlated with inorganic nitrogen (Drira et al., 2008). Blooms of Trichodesmium erythraeum were first detected in July 1988 (Hamza and Ben Maiz, 1990), and since this date, a survey program has been set up to report any water discoloration linked to this species. Hamza et al. (2016) analyzed this long-term series, showing that these blooms occurred on average 2.11 times per year over the period of 1988-2013 and that their development is mainly linked to Saharan dust deposition events prior to the blooms.

The ultraphytoplankton (cells up to $10 \mu \mathrm{m}$ ), studied using flow cytometry, were resolved into five cell groups, Prochlorococcus, Synechococcus, picoeukaryotes, nanoeukaryotes and a group of unidentified cells characterized by a low fluorescence signal (Hamdi et al., 2015). The low ultraphytoplankton abundance was explained by the heterotrophic nanoflagellates feeding on picoplankton, suggesting a tight top-down control of the picoplankton community (Hamdi et al., 2015). More recently, the distribution and phylogenic diversity of picoeukaryote assemblages was studied by Bellaaj Zouari et al. (2018) using biomolecular techniques. They showed the strong impact of both physical and chemical factors on this community and the clear association of some species with water mass properties (e.g., Acantharia and Polycystinea with Levantine water).

\subsection{Zooplankton}

The high protozooplankton abundance reported in the Gulf is characterized by an important ciliate community with 61 taxa identified along the coast and in the open sea (Hannachi et al., 2009) and 56 species with important populations of tintinnids identified along the coastline (Kchaou et al., 2009). Abundances of hetero-nanoflagellates were also recently reported to be a choanoflagellate (Hamdi et al., 2015) and low fluorescence nanoflagellates (Rekik et al., 2014; Hamdi et al., 2015) based on flow cytometry analyses.

Within metazooplankton, copepods represented the dominant group (69-83\% of total abundance), including fourteen (14) families, with Acartiidae (mainly Acartia clausi) and Oithonidae (mainly Oithona nana) being dominant in summer along the coast and near the $50 \mathrm{~m}$ depth (Drira et al., 2010). Small planktonic copepods, including pollutiontolerant species (e.g., Oithona nana, Paracalanus parvus, Harpacticus littoralis and Tisbe battagliai), proliferate in coastal areas characterized by high anthropogenic inputs (Drira et al., 2017). The seasonal zooplankton distribution is characterized by maximum abundance during September under strong summer stratification (Drira et al., 2010). The reproductive strategy (dominance of egg-carrying species allowing preservation of egg viability after predation; see Saint-Jean and Pagano, 1995) and eclecticism in trophic behavior may explain the summer dominance of small copepods (Ben Ltaief et al., 2015). Drira et al. (2010) showed that the spatial distribution of a dominant species was dependent on salinity, suggesting that these species probably escaped the high coastal salinity (38.00) in order to exploit a wide range of food resources, including phytoplankton or animal prey. More generally, Ben Ltaief et al. (2017) suggested that temperature-salinity conditions and the intensity of thermal stratification should explain the space and time successions of zooplankton communities and of key species. Annelid larvae and coastal copepods (Euterpina acutifrons, Oithona nana, Acartia tonsa, etc.) are associated with high salinity shallow mixed and microplankton-rich coastal water, whereas Euphausiids, Amphipods, doliolids, and oceanic copepods (Anomelocera patersoni, Sapphirina darwinii, Candacia bipinnata, etc.) are associated with highly stratified and microplankton-poor waters.

\section{Fisheries and resources}

The Gulf of Gabes is one of the most important fisheries in Tunisia. It accounts for $39.3 \%$ of national production and remains a crucial nursery ecosystem for the Mediterranean.

The Gulf encompasses two important coastal ecosystems that are crucial from a biodiversity standpoint, serving as a nursery for a number of fish species: the Boughrara and El Bibane Lagoons. Boughrara is the largest lagoon in Tunisia, covering approximately 50000 ha and harboring 72 species of fauna (DGPA, 2015), including some 30 fish species. Seventy-eight percent of Tunisia's lagoon fishermen are based here. El Bibane Lagoon, located near the border with Libya, covers 30000 ha (Medhioub and Perthuisot, 1977) and houses approximately 60 fish species distributed among 31 families, with the dominance of the Sparidae family (Djabou, 2006). In 2015, 67 fishing net licenses were issued in the lagoon (DGPA, 2015).

The number of animal species reported in the Gulf of Gabes is 667 (Bradai, 2010), distributed mainly between pisces (227 species), molluscs (171 species), sponges (108 species). The Gulf of Gabes houses 255 of the 348 fish species of Tunisia, with 49 species recorded only in this Gulf (Bradai, 2010). Its biodiversity also consists of 46 species of echinoderms, 6 species of cnidarians, 57 species of bryozoa, 11 species of annelids, 24 species of crustaceans, 17 species of ascidians, 108 species of sponges, and 171 species of molluscs (Afli et al., 2005). Most of the benthic communities in the Mediterranean Sea are present in the Gulf of Gabes, with a benthic fauna characterized by the dominance of invertebrates, such as the bivalves Aloidis gibba, Ruditapes decussatus and Pinctada radiata, the sea urchin Paracentrotus lividus (echinoderm) and the sponges Spongia officinalis and Hippospongia communis (Bradai, 2000).

A defining characteristic of the Gulf of Gabes is the seagrass meadows of Posidonia oceanica, which is the most important across the Mediterranean and one of the largest in the world (Batisse and Jeudy de Grissac, 1998). The meadows are perfect spawning grounds for all marine organisms and a nursery for juvenile fish (Hattour et al., 1995).

The Gulf of Gabes is likely one of the most important areas for marine turtles in the entire Mediterranean (Laurent et al., 1990; Laurent and Lescure, 1994). Three marine turtle species are observed in the Gulf: the rare green turtle Chelonia mydas, the leatherback turtle Dermochelys coriacea, which is regularly observed, and the loggerhead Caretta caretta, which is the most common. In the southeastern coasts, the cetaceans Balaenoptera physalus, Stenella caeruleo-alba, Grampus griseus (Risso's dolphin) and Tursiops truncatus are mentioned (Karaa et al., 2012).

This high biodiversity is threatened by unsustainable fishing, pollution, and exotic species. First, fishing and, particularly, bottom trawling cause a progressive but systematic destruction of Posidonia meadows (Ben Abdallah-Ben Hadj Hamida, 2012). Second, the Gulf of Gabes is facing severe pollution problems, especially from the phosphate industry (Béjaoui et al., 2004). Large areas of Posidonia have disappeared, Cymodocea nodosa is scarce and Caulerpa prolifera has almost completely disappeared. Third, the Gulf of Gabes is being invaded by alien species. Several species, mainly of Indo-Pacific origin, have emerged, such as the bivalve Pinctada radiata currently abundant in the Gulf (Bradai, 2000); the shrimps Metapenaeus monoceros and Trachypenaeus curvirostris that strongly compete with the native shrimps $P$ enaeus kerathurus (Missaoui et al., 1995), Metapenaeus stebbingi (Ben Hadj Hamida-Ben Abdallah et al., 2006) and Rimapenaeus similis (Ben Hadj Hamida-Ben Abdallah et al., 2009); the green alga Caulerpa racemosa 
(Ben Alaya, 1972); the marine phanerogam Halophila stipulacea (Missaoui et al., 2003); the brachyura Eucrate crenata (Zaouali, 1992); and the macroura Portunus segnis (Rabaoui et al., 2015), which have become very abundant. There are also approximately 20 exotic fish species, including Siganus luridus (Ktari and Ktari, 1974), Siganus rivulatus (Ktari and Ktari, 1974), Stephanolepis diaspros (Chakroun, 1966), Parexocoetus mento (Ben Souissi et al., 2004; Bradai et al., 2004), Pempheris vanicolensis (Bradai et al., 2004), Sphyraena chrysotaenia (Bradai et al., 2002), Fistularia commersonii (Ben Souissi et al., 2004), Hemiramphus far (Ben Souissi et al., 2005b), Saurida undosquamis (Ben Souissi et al., 2005b), Atherinomorus lacunosus (Ben Souissi et al., 2006), Upeneus pori (Ben Souissi et al., 2005a), Lagocephalus sceleratus (Jribi and Bradai, 2012), and Rhinobatos halavi (Ben Souissi et al., 2007), originated from the Indo-Pacific, as well as Seriola fasciata (Bradai, 2000), Pisodonophis semicinctus (Bradai et al., 2004), Sphaeroides pachygaster (Bradai et al., 1993), Solea sinegalensis (Zouari-Ktari, 2008), Carcharhinus falciformis (Bradai et al., 2002), Cheilopogon furcatus (Ben Souissi et al., 2005c), and Lagocephalus lagocephalus (Bradai et al., 2004) from the Atlantic.

In 2015, the area of the Gulf of Gabes contained approximately $53 \%$ of the Tunisian fishing fleet and landed approximately $33 \%$ of the national fish production. The number of fishing boats recorded in this area is approximately 6800 , constituted mainly of coastal boats, which represent $94 \%$ of the fleet (DGPA, 2015). The trawler fleet is made up of 270 vessels targeting mainly shrimp, cephalopods (mostly Sepia officinalis), and benthic fish. Approximately $98 \%$ of the trawler fleet operating in the Gulf of Gabes is connected to the port of Sfax (DGPA, 2015). These trawlers have a three-month closed season (trawling is forbidden from July to September), which corresponds to a biological resting period. The fishing sector employs an average of 31,428 sailors, of whom $60 \%$ are employed in coastal fisheries and $12 \%$ in trawlers. In 2015, total landings in the Gulf of Gabes were approximately 43,000 tons, representing approximately $33 \%$ of the Tunisian total landings, and were provided mainly by the coastal fishing boats, purse seine boats, and trawlers, which contributed $41 \%, 30 \%$ and $24 \%$, respectively (Fig. 7). The contributions of these fishing gears to the Tunisian total landings were approximately $55 \%, 24 \%$ and $38 \%$, respectively.

\section{Conclusions}

Based on previous studies, this review describes the main characteristics of the Gulf of Gabes and highlights the different specificities of this ecosystem in order to understand its functioning. It could be interpreted as a reference synthesis and could be used as a support for further investigations.

Several factors interact together to influence the functioning of the Gulf of Gabes ecosystem. The climate, which is pre-Saharan and arid to semiarid, strongly influences the ecosystem functioning, mainly through impacts on physical and biogeochemical features.

The water circulation is primarily influenced by the topography, bottom texture, and meteorological conditions. It is recognized that the tide is particularly strong for the Mediterranean Basin (due to the particular topography characterized by a shallow and flat bottom) and is the most important driver for water circulation in the Gulf.

Compared to other Mediterranean systems, the water temperature and salinity in the Gulf are characterized by some important seasonal variations with relatively high annual means, and the vertical stratification varies with depth and season.

Despite its oligotrophic characteristics, the Gulf of Gabes maintains high productivity. Several studies indicated that Saharan dust enrichment could be considered the most efficient source of nutrients in the Gulf of Gabes. The phytoplankton biomass is dominated by pico- and nanoplanktonic organisms, whereas heterotrophic flagellates and ciliates are important components of the protozooplankton. A high protozoa abundance was reported in the Gulf, as they are the main grazers of the pico- and nanophytoplankton size classes; the microbial food web is likely to be the prevalent trophic pathway in the Gulf of Gabes. The metazooplankton, which constitutes an important link between lower and higher trophic levels, is dominated by small copepods and displays high abundance and biomass compared to other Mediterranean coastal sites.

The Gulf of Gabes, a Mediterranean zone with important biological resources and rich coastal, marine, and freshwater ecosystems is particularly exposed to anthropogenic factors altering its natural features. The stocks are already overfished, and biodiversity is declining, paralleling reductions in submerged aquatic vegetation. Invasive species represent an added pressure on fisheries.

The direct impacts of climate change on fisheries are not well understood. However, it is clear that the Gulf's ecosystems, which act as natural nurseries, may affect marine biodiversity, leading to a decline in traditional fishery species along coastal areas.

Based on a cumulative index of warming, overfishing and pollution effects, the Gulf of Gabes was recently identified as a "'Hot Spot" of anthropogenic pressures (Reygondeau et al., 2014) and thus future research should address these issues at regional, Mediterranean and global scales.

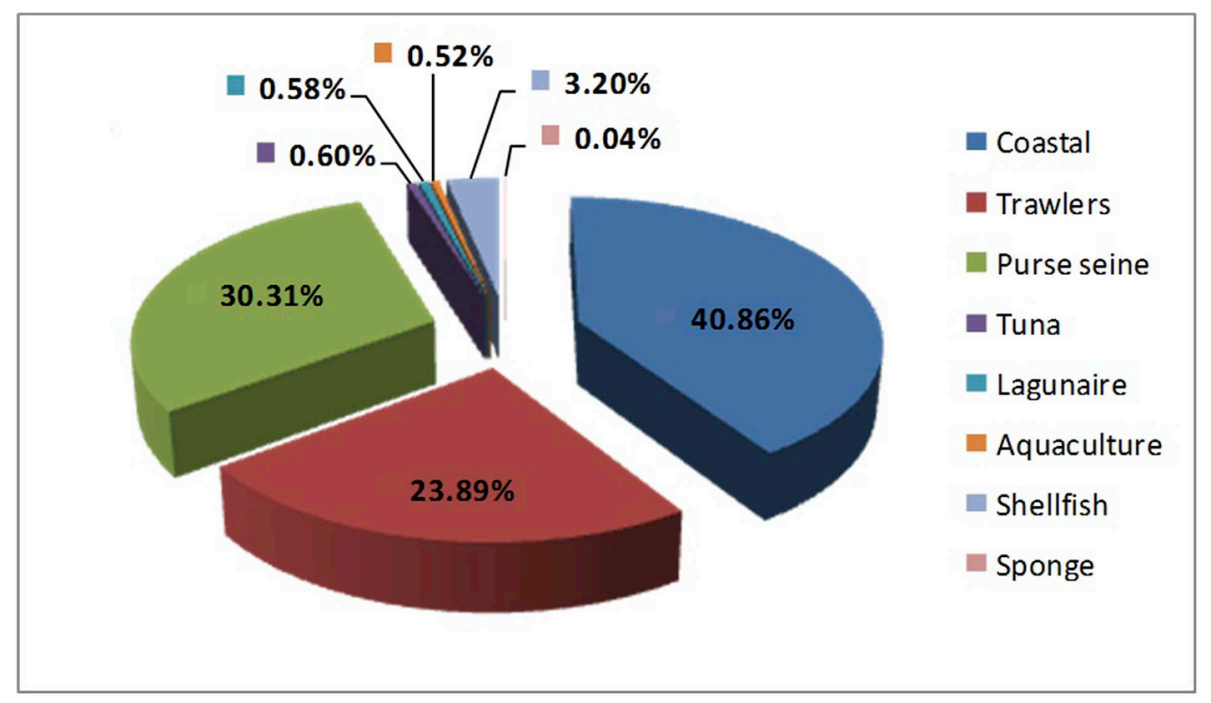

Fig. 7. Distribution of the production by fishing type in the Gulf of Gabes during 2015. 


\section{Acknowledgment}

This review was carried out in part within the framework of the research projects of the Institut National des Sciences et Technologies de la Mer (INSTM), the INCOMMET project (FP7-INCO-2011-6, contract 295009) and the BISTROMED project (funded by MISTRALSENVIMED Program) for the period 2012-2014. We thank the IRD for supporting the Elsevier Language Editing Services.

\section{References}

Abdennadher, J., Boukthir, M., 2006. Numerical simulation of the barotropic tides in the Tunisian shelf and the Strait of sicily. J. Mar. Syst. 63, 162-182.

Abdennadher, M., Bellaaj Zouari, A., Feki Sahnoun, W., Alverca, E., Penna, A., Hamza, A., 2016. Ostreopsis cf. ovata in the Gulf of Gabès (South-Eastern Mediterranean Sea): morphological, molecular and ecological characterization. Harmful Algae 63, 56-67.

Afli, A., Ben Mustapha, K., Jarboui, O., Bradai, M.N., Hattour, A., Langar, H., Sadok, S., 2005. La biodiversité marine en Tunisie. Direction Générale de l'Environnement et de la Qualité de la Vie, Tunisie 20 pp.

Agnew, M.D., Goodess, C.M., Hemming, D., Giannakopoulos, C., Ben Salem, S., Bindi, M., Bradai, N.M., Dibari, C., El-Askary, H., El-Fadel, M., El-Raey, M., Ferrise, F., Grünzweig, J.M., Harzallah, A., Hattour, A., Hatzaki, M., Kanas, D., Kostopoulou, E., Lionello, P., Oweis, T., Pino, C., Psiloglou, B., Abed, S.S., Sánchez-Arcilla, A., Senouci, M., Taleb, M.Z., Tanzarella, A., 2013. Physical and socio-economic indicators. In: Navarra, A., Tubiana, L. (Eds.), Regional Assessment of Climate Change in the Mediterranean. Springer Netherlands, pp. 39-60.

Amari, A., 1984. Contribution à la connaissance hydrologique et sédimentologique de la plateforme des Kerkennah. Thèse de Doctorat. Faculté des Sciences de Tunis 251 pp.

APAL, 2011. Protection des ressources marines et côtière du golfe de Gabes-Inventaire et cartographie du couvert végétal du golfe de Gabès, réseau de surveillance de l'herbier à posidonie. In: Rapport de synthèse final des activités et des réalisations des deux composantes du projet « protection des ressources marines et côtières du golfe de Gabès » financées conjointement par la République Tunisienne et la Banque Internationale pour la Reconstruction et le Développement (BM). Agence de Protection et Aménagement du Littoral, Tunis 312 pp.

APAL, 2012. Atlas des ressources naturelles marines et côtiers du Golfe de Gabes». Agence de Protection et Aménagement du Littoral, Tunis 62 pp.

Atlas Climatique, 1999. Atlas climatique de l'Institut National de la météorologie. Conception et impression office de la topographie et de la cartographie $130 \mathrm{pp}$.

Ayari, M., Allegue, M., Tlili, I., 2008. Etude pour la construction d'un ouvrage de communication au niveau de la chaussée romaine entre la lagune de Boughrara et la mer méditerranée. In: Xèmes Journées Nationales Génie Côtier - Génie Civil, 14-16 Octobre 2008, Sophia Antipolis, 666 pp.

Ayata, S.-D., Irisson, J.-O., Aubert, A., Berline, L., Dutay, J.-C., Mayot, N., Nieblas, A.-E., D'Ortenzio, F., Palmiéri, J., Reygondeau, G., Rossi, V., Guieu, C., 2017. Regionalisation of the Mediterranean basin, a MERMEX synthesis. Prog. Oceanogr. $163,7-20$.

Barhoumi, S., Messaoudi, I., Deli, T., Saied, K., Kerkeni, A., 2009. Cadmium bioaccumulation in three benthic fish species, Salaria basilisca, Zosterisessor ophiocephalus and Solea vulgaris collected from the Gulf of Gabes in Tunisia. J. Environ. Sci. 21, 980-984.

Barlow, R.G., Mantoura, R.F.C., Cummings, D.G., Fileman, T.W., 1997. Pigment chemotaxonomic distributions of phytoplankton during summer in the western Mediterranean. Deep Sea Research II 44, 833-850.

Batisse, M., Jeudy de Grissac, A., 1998. Marine region 3-mediterranean. In: The World Bank, The World Conservation Union (Eds.), Global Representative System of Marine Protected Areas, Great Barrier Reef Marine Park Authority, pp. 77-104.

Bechrawi, A., 1980. La vie rurale dans les oasis de Gabès. Thèse d'Etat. Faculté des lettres de Tunis, Tunisie 301 pp.

Béjaoui, B., Rais, S., Koutitonsky, V., 2004. Modélisation de la dispersion du phosphogypse dans le golfe de Gabès. In: Bulletin de l'Institut National des Sciences et Technologie de la Mer de Salammbô, vol. 31. pp. 103-109.

Bel Hassen, M., Drira, Z., Hamza, A., Ayadi, H., Akrout, F., Issaoui, H., 2008. Summer phytoplankton pigments and community composition related to water mass properties in the Gulf of Gabes. Estuarine. Coastal and Shelf Science 77, 645-656.

Bel Hassen, M., Drira, Z., Hamza, A., Ayadi, H., Akrout, F., Messaoudi, S., Issaoui, H., Aleya, L., Bouain, A., 2009a. Phytoplankton dynamics related to water mass properties in the Gulf of Gabes: ecological implications. J. Mar. Syst. 75, 216-226.

Bel Hassen, M., Hamza, A., Drira, Z., Zouari, A., Akrout, F., Messaoudi, S., Aleya, L., Ayadi, H., 2009b. Phytoplankton-pigment signatures and their relationship to spring summer stratification in the Gulf of Gabes. Estuarine. Coastal and Shelf Science 83, 296-306.

Bel Hassen, M., Hamza, A., Zouari, A., Drira, Z., Akrout, F., Messaoudi, S., 2010. Temporal and seasonal variations of nutrient limitation of phytoplankton biomass in the Gulf of Gabes. Life Environ. 60, 17-26.

Bellaaj Zouari, A., Bel Hassen, M., Balagué, V., Sahli, E., Ben Kacem, M.Y., Akrout, F., Hamza, A., Massana, R., 2018. Picoeukaryotic diversity in the Gulf of Gabès: variability patterns FEKand relationships to nutrients and water masses. Aquat. Microb. Ecol. 81, 37-53.

Beltrando, G., 2004. Les climats, processus, variabilité et risques. Armand Colin, Paris $261 \mathrm{pp}$.

Ben Abdallah-Ben Hadj Hamida, O., 2012. Etude biologique et dynamique de la crevette mouchetee Metapenaeus monoceros (fabricius, 1798) exploitée dans le golfe de Gabès (Tunisie). Thèse de doctorat. Institut National Agronomique de Tunisie, Tunisie $279 \mathrm{pp}$.

Ben Alaya, H., 1972. Répartition est condition d'installation de Caulerparacemosa dans le golfe de Gabès. vol. 2. Bulletin de l'Institut National Scientifique et Technique d'Océanographique et de Pêche de Salammbô, pp. 331-461.

Ben Brahim, M., Hamza, A., Hannachi, I., Rebai, A., Jarboui, O., Bouain, A., Aleya, L., 2010. Variability in the structure of epiphytic assemblages of Posidonia oceanica in relation to human interferences in the Gulf of Gabes, Tunisia. Mar. Environ. Res. 70, 411-421.

Ben Brahim, M., Hamza, A., Ben Ismail, S., Mabrouk, L., Bouain, A., Aleya, L., 2013. What factors drive seasonal variati on of phytoplankton, protozoans and metazoans on leaves of Posidonia oceanica and in the water column along the coast of the Kerkennah Islands, Tunisia? Mar. Pollut. Bull. 71, 286-298.

Ben Hadj Hamida-Ben Abdallah, O., Ben Hadj Hamida, N., Jarboui, O., Missaoui, H., 2006. Première observation de la crevette faucon Metapenaeus stebbingi (Nobili, 1904) dans le golfe de Gabès. Bulletin de l'Institut National des Sciences et Technologies de la Mer de Salammbô 33, 133-136.

Ben Hadj Hamida-Ben Abdallah, O., Ben Hadj Hamida, N., Jarboui, O., Fiorentino, F., Missaoui, H., 2009. Reproductive biology of the speckled shrimp Metapenaeus monoceros (Fabricius, 1798) (Decapoda: Penaeidae) in the gulf of Gabes (southern Tunisia, eastern mediterranean). Cah. Biol. Mar. 50, 231-240.

Ben Ismail, S., Sammari, C., Béranger, K., Lellouche, P., 2010. Atlas des données hydrologiques des côtes tunisiennes. Institut National des Sciences et Technologies de la Mer 169 pp.

Ben Ismail, S., Sammari, C., Gasparini, G.P., Béranger, K., Brahim, M., Aleya, L., 2012. Water masses exchanged through the Channel of Sicily: evidence for the presence of new water masses on the Tunisian side of the channel. Deep-Sea Res. I 63, 65-81.

Ben Ismail, S., Schroeder, K., Sammari, C., Gasparini, G.P., Borghini, M., Aleya, L., 2014. Interannual variability of water mass properties in the Tunisia-Sicily Channel. J. Mar. Syst. 135, 14-28.

Ben Ismail, S., Sammari, C., Béranger, K., 2015. Surface Circulation Features along the Tunisian Coast: Central Mediterranean Sea. $26^{\text {th }}$ IUGG General Assembly, Prague. Czech Republic June 22 - July 2.

Ben Ltaief, T., Drira, Z., Hannachi, I., Bel Hassen, M., Hamza, A., Pagano, M., Ayadi, H., 2015. What are the factors leading to the success of small planktonic copepods in the Gulf of Gabes, Tunisia? J. Mar. Biol. Assoc. U. K. 95 (4), 747-761.

Ben Ltaief, T., Drira, Z., Devenon, J.L., Hamza, A., Ayadi, H., Pagano, M., 2017. How could thermal stratification affect horizontal distribution of depth-integrated metazooplankton communities in the Gulf of Gabes (Tunisia)? Mar. Biol. Res. 13, 3.

Ben Othman, S., 1971. Observations hydrologiques, dragages et chalutage dans le Sud Est tunisien. Bulletin de l'Institut National des Sciences et Technologies de la Mer 2, 103-120.

Ben Othman, S., 1973. Le Sud tunisien (Golfe de Gabès): hydrologie, sédimentologie, flore et faune. Thèse de doctorat. Faculté des Sciences de Tunis, Tunisie 166 pp.

Ben Salem, Z., Drira, Z., Ayadi, H., 2015. What factors drive phytoplankton, ciliates and mesozooplankton communities variations in the polluted Southern coast of Sfax, Tunisia? Environ. Sci. Pollut. Control Ser. 22, 11764-11780.

Ben Souissi, J., Zaouali, J., Bradai, M.N., Quignard, J.P., 2004. Lessepsian migrant fishes off the coast of Tunisian. First record of Fistulariacommersonii (Osteichthyes, Fistularidae) and parexocoetusmento (Osteichthyes, Exocoetidae). Vie Milieu 54, 247-248.

Ben Souissi, J., Mejri, H., Zaouali, J., Capapé, C., 2005a. On the occurrence of the por's goatfish Upeneuspori (mullidae) in southern Tunisia (central mediterranean). Cybium 30, 379-381.

Ben Souissi, J., Trigui El Mnif, N., Mahjoub, M.S., Mejri, H., Quignard, J.P., Capapé, C., Zaouali, J., 2005b. On the recent occurrences of marine exotic species in Tunisian waters. In: Proceedings of the Seventh International Conference on the Mediterranean Coastal Environment, Medcoast 05, 1, Kusadasi, Turkey, pp. 529-540.

Ben Souissi, J., Golani, D., Mejri, H., Capapé, C., 2005c. On the occurrence of Cheilopogon furcatus in the Mediterranean Sea. J. Fish. Biol. 67, 1144-1149.

Ben Souissi, J., Golani, D., Mejri, H., Zaouali, J., Capapé, C., 2006. On the occurrence of Scomberomorus commerson Lacepède, 1800 (Osteichthyes, scombridae) off northern Tunisia (central mediterranean). Cah. Biol. Mar. 47, 215-218.

Ben Souissi, J., Golani, D., Mejri, H., Ben Salem, M., Capapé, C., 2007. First confirmed record of the halave's Guitarfish, Rhinobatoshalavi (Forsskäl, 1775) (Chondrichthyes, Rhinobatidae) in the Mediterranean Sea with a description of a case of albinism in elasmobranchs. Cah. Biol. Mar. 48, 67-75.

Béranger, K., Mortier, L., Gasparini, G.P., Gervasio, L., Astraldi, M., Crepon, M., 2004. The dynamics of the Sicily Strait: a comprehensive study from observations and model. Deep Sea Research II 51, 411-440.

Berman, T., Azov, Y., Townsend, D.W., 1984. Understanding oligotrophic oceans: can the Eastern Mediterranean be a usefu1 model? Coast. Estuar. Stud. 8, 101-112.

Berman, T., Azov, Y., Schneller, A., Walline, P.D., Townsend, D.W., 1986. Extent, transparency and phytoplankton distribution of the neritic waters overlying the Israeli coastal shelf. Oceanol. Acta 9, 439-447.

Berman-Frank, I., Rahav, E., 2012. Dinitrogen fixation as a source for new production in the Mediterranean Sea: a review. In: Stambler, N. (Ed.), Life in the Mediterranean Sea: a Look at Habitat Changes. Nova Science Publishers, New York, pp. 199-226.

Bethoux, J.P., 1977. Contribution à l'étude thermique de la Mer Méditerranéen. Thèse de doctorat. Université de Pierre et Marie Curie, France 201 pp.

Bonaduce, A., Pinardi, N., Oddo, P., Spada, G., Larnicol, G., 2016. Sea-level variability in the Mediterranean Sea from altimetry and tide gauges. Clim. Dyn. 47, 2851-2866.

Bosc, E., Bricaud, A., Antoine, D., 2004. Seasonal and interannual variability in algal biomass and primary production in the Mediterranean Sea, as derived from 4 years of SeaWifs observations. Glob. Biogeochem. Cycles 18, GB1005. 
Bouaziz, R., 2011. Les oueds des environs de Sfax (Tunisie orientale): Géomorphologie et évolution des paysages au cours du quaternaire supérieur. Editions Universitaires Européennes 228 p.

Bouaziz, S., Jedouia, J., Barrierb, E., Angelierb, J., 2003. Néotectonique affectant les dépôts marins tyrrhéniens du littoral sud-est tunisien: implications pour les variations du niveau marin. Compt. Rendus Geosci. 335, 247-254.

Bouaziz, R., Daoud, A., Dahech, S., Beltrando, G., 2005. Apports et limites de l'imagerie spatiale à l'étude des littoraux sableux : cas du littoral de Chaffar, gouvernorat de Sfax (Tunisie méridionale). Photo Interpret. 41, 15-24.

Bourgou, M., Kassah, A., 2008. L'Île de Jerba : Tourisme, Environnement, Patrimoine. Cérès édition $213 \mathrm{p}$.

Bradai, M.N., 2000. Diversité du peuplement ichtyque et contribution à la connaissance des sparidés du golfe de Gabès. Thèse de doctorat d'Etat. Faculté des Sciences de Sfax, Tunisie 595 pp.

Bradai, M.N., 2010. Tunisian fish fauna and the global warming. Rapport de la Commission Internationale pour l'Exploration Scientifique de la Mer Méditerranée 39, 462.

Bradai, M.N., Ghorbel, M., Bouain, A., 1993. Premières observations dans le golfe de Gabès (Tunisie) Spheroidescutaneus (Tetraodontidae). Cybium 1786 pp.

Bradai, M.N., Saidi, B., Ghorbel, M., Jarboui, O., Bouain, A., El Abed, A., Hamza, A., 2002. Statut des espèces exotiques signalées dans les eaux tunisiennes. Actes des 5 èmes Journées Tunisiennes des Sciences de la Mer, Tunisie, pp. 68-69.

Bradai, M.N., Quignard, J.P., Bouain, A., Jarboui, O., Ouannes-Ghorbel, A., Ben Abdallah, L., Zaouali, J., Ben Salem, S., 2004. Ichtyofaune autochtone et exotique des côtes tunisiennes : recensement et biogeography. Cybium 28, 315-328.

Brahim, F., 2001. Le Sahel central et méridional : géomorphologie et dynamique récente du milieu naturel. Thèse doctorat. Faculté Sciences Humaines de Tunis, Université de Tunis. Tunisie, pp. 432.

Brandhorst, W., Messaoud, H., 1977. Les conditions de milieu au large de la côte tunisienne. Bulletin de l'Institut National Scientifique et Technique d'Oceanographie et de Peche Salammbô 4, 129-220.

Calafat, F.M., Jordà, G., Marcos, M., Gomis, D., 2012. Comparison of Mediterranean Sea level variability as givenby three baroclinic models. J. Geophys. Res. 117, C02009.

Chakroun, F., 1966. Capture d'animaux rares en Tunisie. Bulletin de l'Institut national scientifique et technique d'Océanographie et de Pêche de Salammbô 1, 75-79.

Ciappa, A.C., 2009. Surface circulation patterns in the Sicily Channel and Ionian Sea as revealed by MODIS chlorophyll images from 2003 to 2007. Cont. Shelf Res. 29, 2099-2109.

Corsini, G., Grasso, R., Cipollini, P., 2002. Regional bio-optical algorithms for the Alboran Sea from a reflectance model and in situ data. Geophys. Res. Lett. 29, 1-4.

Criado-Aldeanueva, F., Del Rio Vera, J., Garcia-Lafuente, J., 2008. Steric and mass-induced Mediterranean Sea level trends from 14 years of altimetry data. Glob. Planet. Chang. 60, 563-575.

Dahech, S., 2007. Le vent à Sfax (Tunisie), impacts sur le climat et la pollution atmosphérique. Thèse de doctorat, université Paris VII, France 309 pp.

Dahech, S., 2015. Impact de la brise de mer sur le confort thermique au Maghreb oriental. Cybergeo : European Journal of Geography, Environnement, Nature, Paysage, document 695. https://doi.org/10.4000/cybergeo.26555.

Dahech, S., Beltrando, G., 2006. Variabilité du climat de Sfax (Tunisie) entre 1970 et 2002: exemple des températures et du vent. In: Actes du XIXe Colloque de l'Association Internationale de Climatologie, Epernay, pp. 184-190.

Dahech, S., Beltrando, G., 2012a. Observed temperature evolution in the city of Sfax (Middle Eastern Tunisia) for the period 1950-2007. Clim. Change 114, 689-706.

Dahech, S., Beltrando, G., 2012b. Le vent de sable dans le Sud tunisien: Caractéristiques et conséquences pour l'Homme dans l'agglomération de Sfax entre 1965 et 2004. Meteorol. 79, 40-51.

Dahech, S., Beltrando, G., Quenol, H., 2006. Brise de mer et pollution atmosphérique à Sfax (Tunisie). Pollut. Atmosphérique 190, 211-223.

Daly Yahia, M.N., Kefi-Daly Yahia, O., Gueroun, S.K.M., Aissi, M., Deidun, A., Fuentes, V., Piraino, S., 2013. The invasive tropical scyphozoan Rhopilema nomadica Galil, 1990 reaches the Tunisian coast of the Mediterranean Sea. BioInvasions Records 2, 319-323.

Dangeard, L., 1924. Rapport de mission, campagne de « Pourquoi Pas ? en 1923. Imprimerie Nationale, Paris.

Daoud, A., Dahech, S., 2012. La faible résilience de l'agglomération de Sfax (Tunisie méridionale) face au changement climatique. In: Climatologie, numéro spécial, Climats et changement climatique dans les villes, pp. 109-127.

De Gaillande, D., 1970a. Note sur les peuplements de la zone centrale du golfe de Gabès (Campagne Calypso, 1965). Tethys 2, 131-138.

De Gaillande, D., 1970b. Peuplements benthiques de l'herbier de Posidonia oceanica (Delile), de la pelouse à Caulerpa prolifera Lamouroux et du large du golfe de Gabès. Thétys 2, 373-384.

Derbel, H., Châari, M., Neifar, L., 2012. Digenean species diversity in teleost fishes from the gulf of Gabes, Tunisia (western mediterranean). Parasite 19, 129-135.

Dexter, R.V., 1958. The sea-breeze hodograph at Halifax. Bull. Am. Meteorol. Soc. 39, 241-247.

DGPA, 2015. Annuaire des Statistiques des Pêches en Tunisie (Année 2015). Direction Générale de la Pêche et de l'Aquaculture, Tunis.

Djabou, H., 2006. Exploitation halieutique et biodiversité de la lagune d'El Bibane (Sud tunisien). Mastère. Faculté des Sciences de Sfax, Tunisie 106 pp.

D'Ortenzio, F., Marullo, S., Ragni, M., d'Alcalà, M.R., Santoleri, R., 2002. Validation of empirical SeaWiFS chlorophyll-a algorithms retrieval in the Mediterranean Sea: a case study for oligotrophic seas. Rem. Sens. Environ. 82, 79-94.

D'Ortenzio, F., d'Alcalà, M.R., 2009. On the trophic regimes of the Mediterranean Sea: a satellite analysis. Biogeosciences 6, 139-148.

Drira, Z., Hamza, A., Bel Hassen, M., Ayadi, H., Bouaïn, A., Aleya, L., 2008. Dynamics of dinoflagellates and environmental factors during the summer in the gulf of Gabes (Tunisia, eastern Mediterranean Sea). Sci. Mar. 72, 59-71.

Drira, Z., Bel Hassen, M., Hamza, A., Ayadi, H., Rebai, A., Bouaïn, A., Alyea, L., 2009. Spatial and temporal variations of microphytoplankton composition related to hydrographic conditions in the Gulf of Gabes. J. Mar. Biol. Assoc. U. K. 89, 1559-1569.

Drira, Z., Bel Hassen, M., Ayadi, H., Hamza, A., Zarrad, R., Bouaïn, A., Aleya, L., 2010. Copepod community structure related to environmental factors from a summer cruise in the Gulf of Gabes (Tunisia, Eastern Mediterranean Sea). J. Mar. Biol. Assoc. U. K. 90, 145-157.

Drira, Z., Bel Hassen, M., Ayadi, H., Aleya, L., 2014a. What factors drive copepod community distribution in the Gulf of Gabes, Eastern Mediterranean Sea? Environ. Sci. Pollut. Control Ser. 21, 2918-2934.

Drira, Z., Elloumi, J., Guermazi, W., Bel Hassen, M., Hamza, A., Ayadi, H., 2014b. Seasonal changes on planktonic diatom communities along an inshore-offshore gradient in the Gulf of Gabes (Tunisia). Acta Ecol. Sin. 34, 34-43.

Drira, Z., Chaari, D., Hamza, A., Bel Hassen, M., Pagano, M., Ayadi, H., 2016a. Diazotrophic cyanobacteria signatures and their relationship to hydrographic conditions in the Gulf of Gabès, Tunisia. J. Mar. Biol. Assoc. U. K. 1-12.

Drira, Z., Kmiha-Megdiche, S., Sahnoun, H., Hammami, A., Allouche, N., Tedetti, M., Ayadi, H., 2016b. Assessment of anthropogenic inputs in the surface waters of the southern coastal area of Sfax during spring (Tunisia, Southern Mediterranean Sea). Mar. Pollut. Bull. 104, 355-363.

Drira, Z., Kmiha-Megdiche, S., Sahnoun, H., Tedetti, M., Pagano, M., Ayadi, H., 2017. Copepod assemblages as a bioindicator of environmental quality in three coastal areas under contrasted anthropogenic inputs (Gulf of Gabes, Tunisia). J. Mar. Biol. Assoc. U. K. https://doi.org/10.1017/S0025315417001515.

El Melki, T., 1996. Les masses d'air en Tunisie. Thèse de troisième cycle. université de Tunis I, Tunisie 256 pp.

Enajjar, S., Saidi, B., Nejemeddine Bradai, M.N., 2015. The gulf of Gabes (central Mediterranean Sea): a nursery area for sharks and batoids (Chondrichthyes: Elasmobranchii). Cah. Biol. Mar. 56, 143-150.

Farrugio, H., Oliver, P., Biagi, F., 1993. An overview of the history, knowledge, recent and future research trends in Mediterranean fisheries. Sci. Mar. 57, 105-119.

Feki-Sahnoun, W., Hamza, A., Mahfoudi, M., Rebai, A., Bel Hassen, M., 2014. Long-term microphytoplankton variability patterns using multivariate analyses: ecological and management implications. Environ. Sci. Pollut. Control Ser. 21, 11481-11499.

Feki-Sahnoun, W., Hamza, A., Njah, H., Barraj, N., Mahfoudi, M., Rebai, A., Bel Hassen, M.,A., 2017. Bayesian network approach to determine environmental factors controlling Karenia selliformis occurrences and blooms in the Gulf of Gabès, Tunisia. Harmful Algae 63, 119-132.

Feki-Sahnoun, W., Hamza, A., Béjaoui, B., Mahfoudi, M., Rebai, A., Bel Hassen, M. 2018a. Multitable approach to assess the spatial distribution patterns in the structural phytoplankton communities along the coast of the Gulf of Gabès (Eastern Mediterranean Sea, Tunisia). Hydrobiologia 811, 1-23.

Feki-Sahnoun, W., Njah, H., Hamza, A., Barraj, N., Mahfoudi, M., Rebai, A., Bel Hassen, M., 2018b. Using general linear model, Bayesian Networks and Naive Bayes classifier for prediction of Karenia selliformis occurrences and blooms. Ecol. Inf. 43, 12-23.

Galil, B.S., 2000. A sea under siege - alien species in the Mediterranean. Biol. Invasions 2, 177-186.

Gasparini, G.P., Ortona, A., Budillon, G., Astraldi, M., Sansone, E., 2004. The effect of the eastern mediterranean transient on the hydrographic characteristics in the Strait of sicily and in the tyrrhenian sea. Deep-Sea Res. I 52, 915-935.

Geurmazi, W., Drira, Z., Ellouni, J., Bouïn, A., Ayadi, H., 2010. Spatial and vertical distribution of phytoplankton during a winter cruise in the south of the Kerkennah islands in the gulf of Gabes, Tunisia. J. Life Sci. 4, 1-8.

Ghannem, N., Azri, C., Serbaji, M.N., Yaich, C., 2010. Spatial distribution of heavy metals in the coastal zone of "Sfax-Kerkennah" plateau, Tunisia. Environ. Prog. Sustain. Energy 30, 221-233.

Gitelson, A., Karnieli, A., Goldman, N., Yacobi, Y.Z., Mayo, M., 1996. Chlorophyll estimation in the Southeastern Mediterranaen using CZCS images: adaptation of an algorithm and its validation. J. Mar. Syst. 9, 283-290.

Goodess, C.,M., 2013. How is the frequency, location and severity of extreme events likely to change up to 2060? Environ. Sci. Policy 27, S4-S14.

Gualdi, S., Somot, S., May, W., Castellari, S., Déqué, M., Adani, M., Artale, V., Bellucci, A., Breitgand, J.S., Carillo, A., Cornes, R., Dell'Aquila, A., Dubois, C., Efthymiadis, D. Elizalde, A., Gimeno, L., Goodess, C.M., Harzallah, A., Krichak, S.O., Kuglitsch, F.G., Leckebusch, G.C., L'Hévéder, B., Li, L., Lionello, P., Luterbacher, J., Mariotti, A., Navarra, A., Nieto, R., Nissen, K.M., Oddo, P., Ruti, P., Sanna, A., Sannino, G., Scoccimarro, E., Sevault, F., Struglia, V.M., Toreti, A., Ulbrich, U., Xoplaki, E., 2013. Future climate projections. In: Navarra, A., Tubiana, L. (Eds.), Regional Assessment of Climate Change the Mediterranean. Springer, Dordrecht, Netherlands, pp. 53-118.

Hamdi, I., Denis, M., Bellaaj Zouari, A., Khemakhem, H., Hassen, M.B., Hamza, A., Barani, A., Bezac, C., Maalej, S., 2015. The characterisation and summer distribution of ultraphytoplankton in the Gulf of Gabès (Eastern Mediterranean Sea, Tunisia) by using flow cytometry. Cont. Shelf Res. 93, 27-38.

Hamza, A., Ben Maiz, N., 1990. Sur l'apparition du phénomène "d'eau rouge" dans le golfe de Gabès en été 1988. Bulletin de l'Institut National des Sciences et Technologies de la Mer 17, 5-15.

Hamza, I., Feki, W., Hamza, A., Bel Hassen, M., 2016. Long term characterization of Trichodesmium erythraeum blooms in Gabes Gulf (Tunisia). Cont. Shelf Res. 124 95-103.

Hamza-Chaffai, A., Pellerin, J.J.C., 2003. Health assessment of a marine bivalves Ruditapes decussates from the Gulf of Gabes (Tunisia). Environ. Int. 28, 609-617.

Hannachi, I., Drira, Z., Bel Hassen, M., Hamza, A., Ayadi, H., Bouain, A., Aleya, L., 2009. Abundance and biomass of the ciliate community during a spring cruise in the gulf of Gabes (east Mediterranean Sea, Tunisia). Acta protozoologica 47, 293-305. 
Hannachi, I., Drira, Z., Bel Hassen, M., Hamza, A., Ayadi, H., Aleya, L., 2011. Species composition and spatial distribution of abundances and biomass of phytoplankton and ciliates during summer stratification in the Gulf of Hammamet (Tunisia). J. Mar. Biol. Assoc. U. K. 91, 1429-1442.

Harmelin-Vivien, M., Le Direach, L., Bayle-Sempere, J., Charbonnel, E., Garcia-Charton, J., Ody, D., Perez-Ruzafa, A., Renones, O., Sanchez-Jerez, P., Valle, C., 2008. Gradients of abundance and biomass across reserve boundaries in six Mediterranean marine protected areas: evidence of fish spillover? Biol. Conserv. 141, 1829-1839.

Harzallah, A., Bradai, M.N., Ben Salem, S., Hattour, A., 2010. Biogeophysical and social vulnerability indicators: coastal case studies information sheet: gulf of Gabes, Tunisia. In: Agnew, M., Goodess, C. (Eds.), Climate Research Unit, School of Environmental Science. University of East Anglia, Norwich, UK. WWW.page. http:// www.cru.uea.ac.uk./projects/circe/Gabes.html.

Hattour, A., Ben Mustapha, K., Turki, B., Mhetli, M., Tritar, B., 1995. L'écosystème du golfe de Gabès. Commission Internationale pour l'Exploration Scientifique de la Méditerranée (CIESM). CIESM report 34, 33.

Hattour, M.J., Sammari, C., Ben Nassralah, S., 2010. Hydrodynamique du golfe de Gabès déduite à partir des observations de courants et de niveaux. Revue Paralia 3, 1-12.

Hemming, D., Agnew, M.D., Goodess, C.M., Giannakopoulos, C., 2013. Climate impact assessments. In: Navarra, A., Tubiana, L. (Eds.), Regional Assessment of Climate Change in the Mediterranean. Springer, Dordrecht, Netherlands, pp. 61-104.

Hydrotécnica Portuguesa, 1995. Etude générale pour la protection du littoral Tunisien. Rapports, Ministère de l'Equipement et de l'Habitat, Tunisie.

Ignatiades, L., Gotsis-Skretas, O., Pagou, K., Krasakopoulou, E., 2009. Diversification of phytoplankton community structure and related parameters along a large-scale longitudinal east-west transect of the Mediterranean Sea. J. Plankton Res. 31, 411-428.

Jacob, D., Petersen, J., Eggert, B., Alias, A., Christensen, O.B., Bouwer, L.M., Braun, A., Colette, A., Déqué, M., Georgievski, G., Georgopoulou, E., Gobiet, A., Menut, L., Nikulin, G., Haensler, A., 2014. EURO-CORDEX: new high-resolution climate change projections for European impact research. Reg. Environ. Change 14, 563-578.

Jordà, G., Gomis, D., 2013. On the interpretation of the steric and mass components of sea level variability: the case of the Mediterranean basin. J. Geophys. Res.: Oceans 118, 953-963.

Jribi, I., Bradai, M.N., 2012. First record of the lessepsian migrant species Lagocephalus sceleratus (Gmelin, 1789) (Actinopterygii: tetraodontidae) in the central mediterranean. BioInvasions Records 1, 49-52.

Karaa, S., Bradai, M.N., Jribi, I., Attia-El Hili, H., Bouain, A., 2012. Status of cetaceans in Tunisia through analysis of stranding data from 1937 to 2009. Mammalia 76, 21-29.

Katlane, R., Nechad, B., Ruddick, K., Zargouni, F., 2013. Optical remote sensing of turbidity and total suspended matter in the Gulf of Gabes. Arabian Journal of Geosciences 6, 1527-1535.

Kchaou, N., Elloumi, J., Drira, Z., Hamza, A., Ayadi, H., Bouain, A., Aleya, L., 2009. Distribution of ciliates in relation to environmental factors along the coastline of the Gulf of Gabes, Tunisia. Estuarine. Coastal and Shelf Science 83, 414-424.

Khammeri, Y., Hamza, I.S., Bellaaj Zouari, A., Hamza, A., Sahlia, E., Akrout, F., Ben Kacem, M.Y., Messaoudi, S., Bel Hassen, M., 2018. Atmospheric bulk deposition of dissolved nitrogen, phosphorus and silicate in the Gulf of Gabès (South Ionian Basin); implications for marine heterotrophic prokaryotes and ultraphytoplankton. Cont. Shelf Res. 159, 1-11.

Kouka, M., 2015. Le rivage de la petite Syrte : apport de la sédimentologie à l'étude de la progradation du rivage dans les environs de Gigthi (Tunisie méridionale), résultats préliminaires. Physio-Géo 9, 1-16.

Krom, M.D., Emeis, K.C., Van Cappellen, P., 2010. Why is the Eastern Mediterranean phosphorus limited? Prog. Oceanogr. 85, 236-244.

Ktari, F., Ktari, M.H., 1974. Présence dans le golfe de Gabès de Siganus luridus (Rüppel, 1828) et de Siganus rivulatus (Forskal, 1775) (Poissons, siganidae) parasités par Pseudohaliotrematodides polymorphus. In: Bulletin de l'Institut National Scientifique et Technique d'Océanographie et de Pêche de Salammbô, vol. 3. pp. 95-98.

Ktari-Chakroun, F., Azouz, A., 1971. Les fonds chalutables de la région sud-est de la Tunisie (Golfe de Gabès). In: Bulletin de l'Institut National Scientifique et Technique d'Océanographie et de Pêche de Salammbô, vol. 2. pp. 5-47.

Langar, H., Djellouli, A.S., Sellem, F., El Abed, A., 2002. Extension of two Caulerpa species along the Tunisian coast. J. Coast Conserv. 8 (2), 163-167.

Laurent, L., Lescure, J., 1994. L'hivernage des tortues marines caouannes Caretta caretta (L.) dans le sud Tunisien. Terre Vie 49, 63-86.

Laurent, L., Nouira, S., Jeudy, De Grissac, A., Bradai, M.N., 1990. Les tortues marines de Tunisie : premières données. Bull. Soc. Herpetol. Fr. 53, 1-17.

LCHF, 1979. Etude des ports de pêche côtière: Etudes hydrauliques. Laboratoire Central d'Hydraulique de France, Ministère de l'Equipement et de l'Habitat, Tunis, Tunisie.

Le Danois, E., 1925. Recherches sur les fonds chalutables des côtes de de Tunisie (croisière du chalutier "Tanche" en 1924). In: Annales Station Océanographique de Salammbô, vol. 1. pp. 1-56.

LRMV, 2011. Résultats des projets de Recherches (2007-2010). Rapport interne. Laboratoire Ressources Marines Vivantes, INSTM, Tunis 252 pp.

Mancinelli, G., Chainho, P., Cilenti, L., Falco, S., Kapiris, K., Katselis, G., Ribeiro, F., 2017. The Atlantic blue crab Callinectes sapidus in southern European coastal waters: distribution, impact and prospective invasion management strategies. Mar. Pollut. Bull. 119, 5-11.

Marty, J.C., Garcia, N., Raimbault, P., 2008. Phytoplankton dynamics and primary production conditions in the NW Mediterranean Sea. Deep-Sea Res. 55, 1131-1149.

Medhioub, K., Perthuisot, J.P., 1977. Le comportement géochimique des eaux de la Bahiret El Bibane. Conséquences sur la pêche. Condition de milieu et pêche dans la lagune hyper-saline d'El Bibane (Tunisie) : Aménagement des pêches dans les lagunes côtières. Etudes et Revues 61, 175-195.

Millot, C., Candela, J., Fuda, J., Tber, Y., 2006. Large warming and salinification of the
Mediterranean outflow due to changes in its composition. Deep Sea Res. Oceanogr. Res. Pap. 53, 656-666.

Miossec, J.M., Paskoff, R., 1979. Evolution des plages et aménagements touristiques à Jerba (Tunisie): le cas du littoral nord-est de l'île. Méditerranée 35, 99-106.

Missaoui, H., Jarboui, O., Ghorbel, M., Zaouali, J., Jabeur, Ch, Souissi, S., 1995. Sur la présence de nouvelles espèces de crustacés décapodes dans le golfe de Gabès (Tunisie). Bulletin de l'Institut National Scientifique et Technique d'Océanographie et de Pêche de Salammbô 22, 1-14.

Missaoui, H., Mahjoub, M.S., Chalghaf, M., 2003. Sur la présence de la phanérogame marine Halophilastipulacea (Forskal) dans le golfe de Gabès. Bulletin de l'Institut National des Sciences et Technologies de la Mer de Salammbô 30, 111-114.

Molines, J.M., 1991. Modeling the barotropic tides in the strait of Sicily and Tunisian coasts. Oceanol. Acta 14, 241-252.

Morellato, D., 2008. Dynamique des plages sableuses soumises à l'action des vagues, de la marée et des rechargements artificiels. Thèse de doctorat, Ocean, Atmosphere. Universite de Bretagne occidentale, Brest, France 280 pp.

Morzadec-Kerfourn, M.T., 2002. L'évolution des Sebkhas du golf de Gabès (Tunisie) à la transition Pléistocène supérieur-Holocène. Quaternaire. Revue de l'Association Française pour l'Etude du Quaternaire 13, 111-123.

Othmani, A., Béjaoui, B., Chevalier, C., Elhmaidi, D., Devenon, J.L., Aleya, L., 2017. Highresolution numerical modelling of the barotropic tides in the Gulf of Gabes, eastern Mediterranean Sea (Tunisia). J. Afr. Earth Sci. 129, 224-232.

Oueslati, A., 1992. Salt marshes in the gulf of Gabes (southeastern Tunisia): their morphology and recent dynamics. J. Coast Res. 8, 727-733.

Oueslati, A., 2004. In: Littoral et aménagement en Tunisie. Orbis. Tunis 534 pp.

Papaconstantinou, C., Farrugio, H., 2000. Fisheries in the mediterranean. Mediterr. Mar. Sci. 1, 5-18.

Paskoff, R., 1985. Les littoraux : impact des aménagements sur leur évolution. In: In: Gaétan Lessard, G., Dubois, J.M. (Eds.), Géographie physique et quaternaire, vol. 39. Masson, Paris, pp. 107-108 1.

Poizat, C., 1970a. Hydrodynamisme et sédimentation dans le golfe de Gabès (Tunisie). Tethys 2, 267-296.

Poizat, C., 1970b. Les modalités de la sédimentation bioclastique dans le Golfe de Gabès (Tunisie). C. R. Acad. Sci. 270, 676-678.

Poulain, P.M., Zambianchi, E., 2007. Surface circulation in the central Mediterranean Sea as deduced from Lagrangian drifters in the 1990s. Cont. Shelf Res. 27, 981-1001.

Rabaoui, L., Balti, R., El Zrelli, R., Tlig-Zouari, S., 2013. Assessment of heavy metal pollution in the gulf of Gabes (Tunisia) using four mollusc species. Mediterr. Mar. Sci. $15,45-58$.

Rabaoui, L., Arculeo, M., Mansour, L., Tlig-Zouari, S., 2015. Occurrence of the lessepsian species Portunus segnis (Crustacea: Decapoda) in the Gulf of Gabes (Tunisia): first record and new information on its biology and ecology. Cah. Biol. Mar. 56, 169-175.

Rekik, A., Denis, M., Dugenne, M., Barani, A., Maalej, S., Ayadi, H., 2014. Seasonal distribution of ultraphytoplankton and heterotrophic prokaryotes in relation to abiotic variables on the north coast of Sfax after restoration. Mar. Pollut. Bull. 84, 280-305.

Reygondeau, G., Irisson, J.-O., Ayata, S., Gasparini, S., Benedetti, F., Albouy, C., Hattab, T., Guieu, C., Koubbi, P., 2014. Definition of the Mediterranean Eco-Regions and Maps of Potential Pressures in These Eco-Regions. Technical Report. Deliverable Nr. 1.6. FP7-PERSEUS project.

Rizzi, J., Gallina, V., Torresan, S., Critto, A., Gana, S., Marcomini, A., 2016. Regional Risk Assessment addressing the impacts of climate change in the coastal area of the Gulf of Gabes (Tunisia). Sustainability Science 11, 455-476.

Saint-Jean, L., Pagano, M., 1995. Egg mortality through predation in egg-carrying zooplankters. Studies on Heterobranchuslongifilis larvae fed on copepods, cladocerans and rotifers. J. Plankton Res. 17, 1501-1512.

Sammari, C., Millot, C., Taupier, Letage, I., Stefani, A., Brahim, M., 1999. Hydrological characteristics in the Tunisia-Sardinia-Sicily area during spring 1995. Deep-Sea Res. I $46,1671-1703$.

Sammari, C., Koutitonsky, V., Moussa, M., 2006. Sea level variability and tidal resonance in the Gulf of Gabes, Tunisia. Cont. Shelf Res. 26, 338-350.

Sanchez-Arcilla, A., Cesar Mosso, C., Sierra, J.P., Mestres, M., Harzallah, A., Senouci, M., El Raey, M., 2011. Climatic drivers of potential hazards in Mediterranean coasts. Reg. Environ. Change 11, 617-636.

Seurat, L.G., 1924. Observations sur les limites, les faciès et es associations de l'étage intercotidal de la petite Syrte (Golfe de Gabès). Bulletin de la Station Océanographique de Salammbô, Tunis 372 pp.

Seurat, L.G., 1929. Observations nouvelles sur les faciès et les associations animales de l'étagé intercotidal de la petite Syrte. Bulletin de la Station Océanographique de Salammbô, Tunis 372 pp.

Seurat, L.G., 1934. Formations littorales et estuaires de la Syrte mineure (Golfe de Gabès). Bulletin de la Station Océanographique de Salammbô, Tunis 3265 pp.

Sorgente, R., Drago, A.F., Ribotti, A., 2002. Seasonal variability in the central Mediterranean Sea circulation. Ann. Geophys. 21, 299-322.

Sorgente, R., Olita, A., Oddo, P., Fazioli, L., Ribotti, A., 2011. Numerical simulation and decomposition of kinetic energy in the Central Mediterranean: insight on mesoscale circulation and energy conversion. Ocean Sci. 7, 503-519.

Taieb, D., Ben Brahim, A., 2014. Chemistry and mineralogy studies of PM10 atmospheric aerosols in the Gulf of Gabès, SouthTunisia. Int. J. Energy Technol. Policy 10, 125-143.

Taylor, K.E., Stouffer, R.J., Meehl, G.A., 2012. An overview of CMIP5 and the experiment design. Bull. Am. Meteorol. Soc. 93, 485-498.

Thingstad, T.F., Zweifel, U.L., Rassoulzadegan, F., 1998. Limitation of heterotrophic bacteria and phytoplankton in the northwest Mediterranean. Limnol. Oceanogr. 43, 33-44.

Thingstad, T.F., Krom, M.D., Mantoura, R.F.C., Flaten, G.A.F., Groom, S., Herut, B., Kress, N., Law, C.S., Pasternak, A., Pitta, P., Psarra, S., Rassoulzadegan, F., Tanaka, T. 
Tselepides, A., Wassmann, P., Woodward, E.M.S., Riser, C.W., Zodiatis, G., Zohary, T., 2005. Nature of phosphorus limitation in the ultra-oligotrophic eastern Mediterranean. Sciences 309, 1068-1071.

Tlig-Zouari, S., Rabahoui, L., Irathni, I., Ben Hassine, O.K., 2009. Distribution, habitat and population densities of the invasive species Pinctata radiata (Mollusca: Bivalvia) along the Northern and Eastern coasts of Tunisia. Cah. Biol. Mar. 50, 131-142.

Tounsi, K., 1998. Modélisation numérique de la circulation de l'eau de mer dans le Golfe de Gabès. Colloque International, l'observation spatiale: un outil pour l'étude du bassin méditerranéen, Environnement côtier, Tunis, 23-27 novembre. Edition CNESDélégation à la communication, France.

Tsimplis, M., Proctor, R., Flather, R., 1995. A two dimensional tidal model for the Mediterranean Sea. J. Geophys. Res. 100, 16223-16239.

Tudela, S., 2004. Ecosystem effects of fishing in the Mediterrean: an analysis of the major threars of fishing gear and practices to biodiversity and marine habitats. In: Study and Review, vol. 74 FAO, Rome 44 pp.

Ulbrich, U., Xoplaki, E., Dobricic, S., Garcia-Herrera, R., Lionello, P., Adani, M., Baldi, M., Barriopedro, D., Coccimiglio, P., Dalu, G., Efthymiadis, D., Gaetani, M., Galati, M.B., Gimeno, L., Goodess, C.M., Jones, P.D., Kuglitsch, F.G., Leckebusch, G.C., Luterbacher, J., Marcos-Moreno, M., Mariotti, A., Nieto, R., Nissen, K.M., Pettenuzzo, D., Pinardi, N., Pino, C., Shaw, A.G.P., Sousa, P., Toreti, A., Trigo, R.M., Tsimplis, M., 2013. Past and current climate changes in the mediterranean region. In: In: Navarra, A., Tubiana, L. (Eds.), Regional Assessment of Climate Change in the Mediterranean, Volume 1, Air Sea and Precipitation and Water, vol. 1. Springer Dordrech Heidelberg, New York, London, pp. 9-49. https://doi.org/10.1007/978-94-0075781-3.
Vidussi, F., Claustre, H., Manca, B.B., Luchetta, A., Marty, J.C., 2001. Phytoplankton pigment distribution in relation to upper thermocline circulation in the eastern Mediterranean Sea during winter. J. Geophys. Res. 106, 19939-19956.

WAM-DI Group, 1988. The WAM model-a third generation ocean wave prediction model. J. Phys. Oceanogr. 18, 1775-1810.

Worm, B., Barbier, E., Beaumont, N., Duffy, J.E., Folke, C., Halpern, B.S., Jackson, J.B.C., Lotze, H.K., Micheli, F., Palumbi, S.R., Sala, E., Selkoe, K.A., Stachowicz, J.J., Watson, R., 2006. Impacts of biodiversity loss on ocean ecosystem services. Science 314 787-790.

Yacobi, Y., Zohary, T., Kress, N., Hecht, A., Robarts, R.D., Wood, A.M., Li, W.K.W., 1995 Chlorophyll distribution throughout the southeastern Mediterranean in relation to the physical structure of the water mass. J. Mar. Syst. 6, 179-190.

Zairi, M., Rouis, M., 1999. Impacts environnementaux du stockage du phosphogypse à Sfax (Tunisie). Bull. Lab. Ponts Chaussees 219, 29-40.

Zaouali, J., 1992. Présence d'Eucratescrenata (Crustacea, Decapoda, Brachyura) dans le golfe de Gabès. Mar. Life 2, 53-56.

Zenetos, A., Çinar, M.E., Pancucci-papadopoulou, A.M., Harmelin, J.G., Furnari, G., Andaloro, F., Bellou, N., Streftaris, N., Zibrowius, H., 2005. Annotated list of marine alien species in the Mediterranean with records of the worst invasive species. Mediterr. Mar. Sci. 6 (2), 63-118.

Zouari-Ktari, R., 2008. Inventaire des poisons exotiques sur les côtes tunisiennes et Etude de l'écobiologie de deux espèces lesseptiennes: Stephanolepisdiaspros et Sphyraenachrysotaenia. Thèse de doctora. Faculté des Sciences de Sfax, Tunisie 222 pp. 